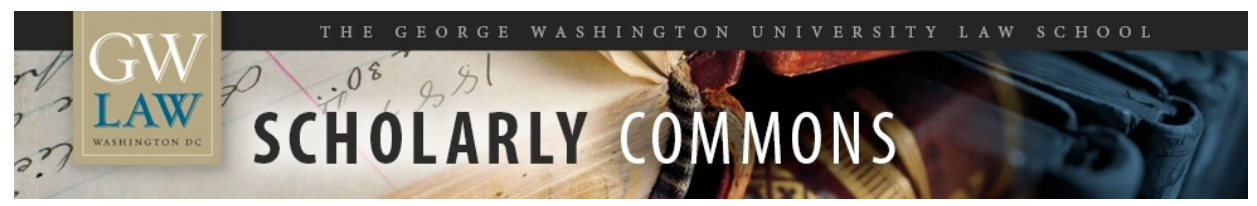

\title{
Romeo and Juliet Online and in Trouble: Criminalizing Depictions of Teen Sexuality
}

Pawn Ghisunziatdaitional works at: https://scholarship.law.gwu.edu/faculty_publications George Washington University Law School, dnunziato@law.gwu.edu

Part of the Law Commons

\section{Recommended Citation}

As teenagers explore their sexuality and seek to memorialize and exchange information related to their sexual development, their instantaneous ability to memorialize and share images with others, via cell phones or the Internet, presents a host of new problems to which our society must respond intelligently. The recent trend of harshly punishing these teens under the child pornography regime is not an intelligent solution. In light of this wave of prosecutorial overreaching, state and federal child pornography laws should be revised to specifically exempt sexting by minors from the reach of such laws. Child pornography laws were created to punish and deter a far different class of conduct-the conduct of adult pedophiles creating and disseminating images that depict sexual abuse of their child victims in a commercial context-not the conduct of older minors using technology to explore their sexuality and voluntarily exchange images with one another. Non-obscene depictions of nudity or sexual conduct created by teens and exchanged voluntarily among themselves for noncommercial purposes should be specifically excluded from the applicable definitions of child pornography and similar crimes. Instances of sexting, however, should not necessarily go unpunished, as they may constitute harmful invasions of the subject's privacy. In cases in which nude or sexually themed images of minors, which were initially created with the subject's consent, are disseminated or otherwise made available without or beyond the scope of the subject's consent, such conduct should be cognizable as actionable invasions of the subject's privacy under the publication of private facts branch of this common law tort. The subject should be able to seek relief not only against the individual who made such images available without her consent, but also against a website that continues to host such images after being notified of their presence. Websites that continue to facilitate the hosting of such images after the subject requests their removal should lose their immunity for hosting such content and should be held liable for facilitating the invasion of the subject's privacy.

This Article is brought to you for free and open access by the Faculty Scholarship at Scholarly Commons. It has been accepted for inclusion in GW Law Faculty Publications \& Other Works by an authorized administrator of Scholarly Commons. For more information, please contact spagel@law.gwu.edu. 


\title{
Romeo and Juliet Online and In Trouble: Criminalizing Depictions of Teen Sexuality ( $c$ u 18r: $g 2 g$ jail)
}

\author{
- Dawn C. Nunziato ${ }^{1}$
}

[T]eenagers engaging in sexual activity ... is a fact of modern society and has been a theme in art and literature throughout the ages. ${ }^{2}$

\section{Introduction}

Consider the tales of Alice and Bob and Carol and Dave, two sets of young lovers. Alice and Bob decide one night, in the midst of their lovemaking, to memorialize the event and take some racy—but not obscene—pictures with Bob’s cell phone. Across town, Carol and Dave have the same idea, and Dave takes similar pictures with his cell phone. Bob and Dave decide to share these images with their lovers via text messaging using their cell phones or by uploading them onto their personal computers. Perhaps Bob and Dave take the further step of sharing these images with others.

Fast-forward six months. As a result of his actions, Bob is facing the possibility of life in prison, while Dave's actions are not even plausibly criminal. Wherein lies the difference? Bob and his lover are seventeen years old, while Dave and his lover are eighteen. Because Bob’s lover is under the age of majority, he is subject to far more severe punishment than is Dave. This anomalous result contravenes our general expectations of our legal system, which imposes gentler punishments on minors than on adults. ${ }^{3}$

\footnotetext{
${ }^{1}$ Professor of Law, The George Washington University Law School. I am grateful to Dean Frederick Lawrence for his generous financial support. I am also thankful for the helpful comments of Jonathan Lowy, for the excellent editorial assistance of Pat Balakrishnan, for the superb research assistance of Robert Arcamona, Thomas Hayne, Bridget Rochester, Megan Zaidan, and Kenneth Rodriguez.

${ }^{2}$ Ashcroft v. Free Speech Coalition, 535 U.S. 234, 246 (2002).

${ }^{3}$ See, e.g., N.Y. PENAL LAW §§ 70.00-70.10 (McKinney 2009) (setting lower minimum and maximum prison terms for juveniles); IOWA CODE ANN. § 903.1(1)(a), (3) (West Supp. 2011) (allowing for a juvenile’s simple
} 
Enter the world of "sexting," where prosecutors throughout the United States have invoked the regime of child pornography to impose harsh penalties on those involved with creating, possessing, or distributing sexually themed images of minors, as Part II discusses. ${ }^{4}$ Because the subject of Bob’s photographs is seventeen years old, under federal and state child pornography laws Bob can be criminally charged with creating, possessing, and distributing child pornography. ${ }^{5}$ In several instances throughout the country, prosecutors have wielded their power to go after minors such as Bob who, with the help of new technologies like cell phones, web cams, e-mail, and social networking sites, create and exchange sexually themed images of themselves and their intimate acquaintances.

Bob’s conduct—taking and sharing a photograph of a seventeen-year-old girl in a state of undress or engaged in a sexual act—-technically falls within most state and federal child pornography laws. However, those laws were created to punish and deter a far different class of conduct—adults' creation and dissemination of images that depict sexual abuse of child victims. The creation and dissemination of true child pornography is a universally condemned act that is appropriately subject to some of the harshest penalties under the law. This Article contends that Bob's conduct, however, is not true child pornography and the law should not treat it as such. Federal and state child pornography laws should be revised to expressly exempt Bob’s conduct from their reach. Although it may be proper to hold Bob liable for violating Alice's privacy if he shares such images without Alice's consent, he should not be subject to the same penalties as a

misdemeanor sentence to consist of community service or a fine up to $\$ 100$, while an adult must pay $\$ 50$ to $\$ 100$ or serve up to thirty days in prison).

${ }^{4}$ See examples infra, text accompanying notes 9-61.

${ }^{5}$ See infra Part III. 
true child pornographer. Moreover, Bob and Alice enjoy a First Amendment right to create and share depictions of themselves engaged in sexual activity to which they can legally consent.

Part II of this Article analyzes some recent instances in which minors were threatened with and subject to child pornography charges for sexting. Part III examines the law of child pornography and the stringent constitutional requirements imposed by the Supreme Court upon legislative efforts to proscribe sexually themed content involving minors. Part IV then explores the constitutional rights enjoyed by minors generally and minors' right to engage in sexually themed expression specifically. Part V proposes revisions to state child pornography laws to exempt acts of sexting from their reach. Finally, Part VI contends that while sexting should not be criminally punishable as child pornography, it should be actionable as an invasion of the subject's privacy if the subject did not consent. Further, social networking sites should not be immune from liability for facilitating such invasions of privacy.

\section{The Back Story: Recent Sexting Prosecutions}

Over the past several years, as cell phones with built-in digital cameras and social networking sites facilitating the posting of digital images have become increasingly popular, teenagers (among others) have begun using these technologies with greater frequency. Many of these teens, who have just begun exploring their sexuality, use these technologies to engage in what has become known as "sexting"- the taking and sharing of sexually themed images of themselves or others via their cell phones or using web cams in conjunction with popular social networking sites like MySpace and Facebook. Teens habitually use these technologies to connect with their peers in general by talking, texting, and creating and sharing images, video, and audio. They have also increasingly used cell phones and social networking sites to explore

their sexuality by exchanging sexually themed communications of all types. This confluence of sexual coming of age and ever-advancing technologies has changed the means teenagers use to 
express themselves, but the underlying messages they express are largely the same as those of prior generations and as old as Shakespeare's tale of star-crossed young lovers.

One such means of exploration and communication is sexting. A 2008 survey found that approximately twenty percent of all teenagers between thirteen and nineteen years old have sent or posted nude or semi-nude pictures of themselves, including twenty-two percent of teen girls, eighteen percent of teen boys, and eleven percent of younger teen girls between the ages of thirteen and sixteen. ${ }^{6}$ A survey released in December 2009 by the Pew Research Center’s Internet and American Life Project (Pew Report) made similar findings, including that fifteen percent of cell-phone owning teenagers ages twelve to seventeen have received a sexually suggestive nude or semi-nude image or video of someone they know via text message. ${ }^{7}$ The Pew Report also examined the social contexts in which teenagers engage in such communications and found that sexting occurs most often in the following contexts: exchanges of images solely between two romantic partners; exchanges between partners that are then shared outside the relationship; and exchanges between people who are not yet in a relationship, but where one person hopes to enter into such a relationship. According to the Pew Report,

Sexually suggestive images have become a form of relationship currency. ... These images are shared as a part of or instead of sexual activity, or as a way of starting or maintaining a relationship with a significant other. And they are also passed along to friends for their entertainment value, as a joke or for fun. ${ }^{8}$

\footnotetext{
${ }^{6}$ Nat’l Campaign to Prevent Teen \& Unplanned Pregnancy, SeX And TeCh: Results From a SuRvey OF TEENS AND YOUNG ADULTS (2008), available at www.thenationalcampaign.org/sextech/PDF/SexTech_Summary.pdf. The study makes clear, however, that the survey respondents do not constitute a probability sample, as the respondents were selected from those who volunteered to participate in the marketing company’s online surveys.

${ }^{7}$ Amanda Lenhart, Pew Research Ctr., Teens and Sexting: How and Why Minor TeEns are Sending SeXually Suggestive Nude or NeArly Nude Images Via TeXt Messaging, (2009) [hereinafter Pew Report], available at http://pewresearch.org/assets/pdf/teens-and-sexting.pdf.

8 Teens and Sexting: Overview, PEW InTERnET (Dec. 15, 2009), http://www.pewinternet.org/Reports/2009/Teens-and-Sexting.aspx; see also PEW REPORT, supra note 7 . In other key findings, the Report found that there was no gender difference in the sending of sexting images, that older teens
} 
As challenging as it may be for many concerned parents, teenagers' use of such technology for general purposes has become an integral part of their creativity, self-actualization, and socialization in today's inter-networked society. But the ability to capture images and video by simply pressing a button on a palm-sized device that is always at hand can create serious problems for both the would-be subject and the photographer or videographer. This is especially true when the images captured are of an embarrassing or intimate nature. The ability to instantaneously capture and share images with others, via cell phones or the Internet, presents a host of new problems. The question becomes how to respond reasonably, effectively, and compassionately to the problems that teenagers' use and misuse of new technologies raises. This Article contends that the response of throwing the book at teenagers—in particular, the draconian book of child pornography laws—is unduly harsh, unreasonable, and indeed violates these teenagers' (and their parents') First Amendment and privacy rights.

In several states, teenagers engaging in acts of sexting have been arrested for child pornography and related crimes. ${ }^{9}$ In some cases, teenagers were threatened with prosecution and faced severe, life-altering sanctions for engaging in such conduct. Although such conduct should not be encouraged, it should not be the subject of child pornography prosecution, either. Consider the cases of three girls from Pennsylvania—Marissa Miller, Grace Kelly, and (the pseudonymous) Nancy Doe. About three years ago, when Marissa and Grace were twelve or thirteen, they attended a party where some pictures were taken. Some of these pictures show

are much more likely to send and receive these images, that more intense users of cell phones are more likely to receive sext images, and that eighteen percent of teen cell phone owners with unlimited texting plans have received such images compared with eight percent of teens on limited plans and three percent of teens who pay per message. See Anne Collier, Sexting: New Study \& the 'Truth or Dare' Scenario, ConNECT SAFEly (Dec. 15, 2009), available at http://www.connectsafely.org/NetFamilyNews/sexting-new-study-a-the-truth-or-dare-scenario.html.

${ }^{9}$ Some examples include Alabama, Florida, New Jersey, New York, Michigan, Ohio, Pennsylvania, Texas, Utah, Virginia, Washington, and Wisconsin. See Judith Levine, What's the Matter with Teen Sexting?, AM. PROSPECT (Feb. 2, 2009), http://www.prospect.org/cs/articles?article=whats_the_matter_with_teen_sexting. 
Marissa and her longtime friend Grace from the waist up. ${ }^{10}$ They are wearing opaque training bras and lying side by side, and one of them is talking on the phone while the other is making a peace sign. ${ }^{11}$ In another photograph, Nancy Doe is standing outside of a shower with a towel wrapped around her body beneath her breasts. ${ }^{12}$ None of these photographs depict sexual activity of any kind, and while the picture of Nancy Doe depicted her partially nude, the pictures of Marissa and Grace did not. In October 2008, some time after the pictures were taken, school officials discovered these photographs on several students' cell phones. ${ }^{13}$ The school officials confiscated the students' cell phones and turned them over to George Skumanick, the District Attorney of Wyoming County, Pennsylvania, who initiated an extensive and ill-conceived criminal investigation into this matter. ${ }^{14}$

In February 2009, District Attorney Skumanick wrote a letter to the parents of Marissa, Grace, and Nancy, as well as to the parents of about twenty other students who were depicted in those photos or found to have the photos on their cell phones. ${ }^{15}$ In his letter, Skumanick threatened the students with child pornography charges unless those involved agreed to the equivalent of a guilty plea. ${ }^{16}$ This included being placed on probation and attending a reeducation program devised to help the girls "gain an understanding of how their actions were

\footnotetext{
${ }^{10}$ Miller v. Mitchell, 598 F.3d 139, 144 (3d Cir. 2010).

${ }^{11}$ Complaint at para. 22, Miller v. Skumanick, 605 F. Supp. 2d 634 (M.D. Pa. 2009) (No. 3:09cv540).

${ }^{12}$ Miller, 598 F.3d at 144.

${ }^{13}$ Id. at 143.

${ }^{14} I d$.

${ }^{15} I d$.

${ }^{16}$ Miller, 598 F.3d at 143-44. Skumanick advised the girls and their parents that in order to avoid charges, they must "finalize the paperwork for [an] informal adjustment," which is the equivalent of "a guilty plea in the juveniledelinquency context allowing for probation before judgment." Complaint, supra note 11, at para. 43 (citing 42 PA. CONS. STAT. ANN. § 6323).
} 
wrong" and "what it means to be a girl." ${ }^{17}$ In his letter, the district attorney invited the parents to attend a meeting to discuss the details of the program. ${ }^{18}$ Skumanick informed the parents that while participation in the re-education program was "voluntary," he would file charges against students who did not participate in or successfully complete the program. ${ }^{19}$ He also informed a group of parents and students that he had the authority to prosecute those involved in making available pictures of girls photographed in their underwear, or even of girls photographed wearing bikinis. ${ }^{20}$ The criminal statutes with which the students were charged carry seven-year prison sentences and juveniles convicted of these charges would have permanent records, since the charges are felonies. ${ }^{21}$ Furthermore, if convicted of such offenses, juveniles over fourteen years of age would be required under the state's version of Megan's Law to register as sex offenders for at least ten years and to have their names and pictures displayed on the state's sexoffender website. ${ }^{22}$ At the meeting, Skumanick informed the parents that he was prepared to file felony charges against any of their children who refused to agree to his deal within 48 hours. ${ }^{23}$ The vast majority of the parties chose to accept the district attorney's deal. ${ }^{24}$ The parents of Marissa Miller, Grace Kelly, and Nancy Doe instead opted to sue the district attorney for,

\footnotetext{
${ }^{17}$ Miller v. Skumanick, 605 F. Supp. 2d 634, 638 (M.D. Pa 2009), aff'd sub nom. Miller v. Mitchell, 598 F.3d 139, 144 (3d Cir. 2010); see also Press Release, Am. Civil Liberties Union, ACLU Sues Wyoming County D.A. for Threatening Teenage Girls with Child Pornography Charges Over Photos of Themselves, (Mar. 25, 2009), http://www.aclu.org/technology-and-liberty/aclu-sues-wyoming-county-da-threatening-teenage-girls-childpornography-charg; Shannon P. Duffy, ACLU Sues NE Pa. DA over Threats Leveled at Teens: Criminal Consequences of 'Sexting' at Issue in Federal Case, LEGAL INTELLIGENCER, Mar. 26, 2009, at 1.

${ }^{18}$ Miller v. Mitchell, 598 F.3d at 144.

${ }^{19} I d$.

${ }^{20}$ Press Release, ACLU, supra note 17.

${ }^{21}$ Complaint, supra note 11 , at para. 16.

${ }^{22}$ Miller v. Skumanick, 605 F. Supp. 2d at 638 (citing 42 PA. CONS. STAT. § 9791 (2010)).

${ }^{23}$ Complaint, supra note 11 , at para. 34 .

${ }^{24} \mathrm{Id}$. at para. 45 ("[E]very parent and minor, except the three families represented in this action, acceded to Skumanick’s demands under threat of felony prosecution and accepted the informal adjustment.”).
} 
among other things, violating their children’s First Amendment rights. ${ }^{25}$ Specifically, the parents alleged that the district attorney violated their children's rights by retaliating against their children for exercising those rights. ${ }^{26}$ Were it not for the legal challenge brought by the parents of Marissa Miller, Grace Kelly, and Nancy Doe, the district attorney would have enjoyed unfettered discretion to threaten dozens of teenagers with child pornography-related charges premised on acts of sexting. ${ }^{27}$

Consider further the case of A.H., a sixteen-year-old Florida teenager, and her seventeenyear-old boyfriend J.G.W., who took digital photographs of themselves naked and engaged in sexual activity. ${ }^{28}$ The couple uploaded these photographs to A.H.’s home computer and emailed them to J.G.W., who could then access them on his home computer. ${ }^{29}$ The couple did not further share these images with anyone else. ${ }^{30}$ As a result, both A.H. and J.G.W. faced seconddegree felony charges under Florida’s child pornography laws, which prohibit individuals from “producing, directing or promoting a photograph or representation that they knew to include the sexual conduct of a child.”31 J.G.W. also faced one count of possession of child pornography. ${ }^{32}$

25 Complaint, supra note 11, at paras. 4-5.

${ }^{26}$ Miller v. Mitchell, 598 F.3d 139, 147 (3d Cir. 2010). Retaliation for the exercise of constitutionally protected rights "is itself a violation of rights secured by the Constitution" and is actionable under 42 U.S.C. § 1983. The Third Circuit decision is discussed infra at text accompanying notes 205-211.

${ }^{27}$ However, while this case was on appeal, Skumanick was defeated by Jeff Mitchell in the November 2009 election, in the campaign for which Skumanick's prosecutorial decision to pursue this case was an issue. While it is impossible to say if this case was determinative, Skumanick had been in office since 1989 and his defeat was somewhat of a surprise. See Robert L. Baker, Mitchell Upsets DA Skumanick, WYOMING COUNTY PRESS EXAMINER (Nov. 11, 2009), http://wcexaminer.com/index.php/archives/news/7550.

${ }^{28}$ A.H. v. State, 949 So. 2d 234, 235 (Fla. Dist. Ct. App. 2007).

${ }^{29} I d$.

${ }^{30}$ Id. at 239-40 (Padovano, J., dissenting).

${ }^{31}$ Id. at 235 (majority opinion) (citing FLA. STAT. § 827.071(3) (2005)).

${ }^{32}$ See id. at 235 n.1 (noting that he was charged under FLA. STAT. § 827.071(5)). 
A.H. contested these charges, claiming that criminal prosecution under the state's child pornography statute violated her constitutional rights, including her right to privacy. ${ }^{33}$ She maintained that the Florida constitution protects her right to engage in sexual activity with her boyfriend and that her right to privacy allows her to memorialize these actions in digital images and to share these photographs with her boyfriend. ${ }^{34}$ A.H. further claimed that the state's action was unconstitutional on the ground that prosecuting her for felony child pornography was not the least intrusive means of advancing any compelling state interest in preventing such behavior. ${ }^{35}$ The court disagreed, holding that the state has a compelling interest in protecting children from sexual "exploitation," regardless of whether the person charged is an adult or a minor (or the “child” herself). ${ }^{36}$ The court held that prosecution under the child pornography statute is the least intrusive means of furthering the state’s interest and that A.H. did not enjoy a reasonable expectation of privacy under the circumstances to create or disseminate photographs of her consensual sexual activities. ${ }^{37}$

Consider further the case of Phillip Alpert, a high school student who, at the age of seventeen, had been involved in a two-year-long relationship with a sixteen-year-old girl. ${ }^{38}$ One night, his girlfriend, with whom he shared many intimacies, e-mailed him a nude picture of herself. ${ }^{39}$ The picture depicted neither a sexual act nor an obscene pose, but rather simply

\footnotetext{
${ }^{33}$ Id. at 236.

${ }^{34}$ Id. (noting that A.H. relied on FLA. CONST. art. 1, § 23 (1998)).

${ }^{35} I d$.

${ }^{36} I d$.

${ }^{37}$ Id. at 235, 238.

${ }^{38}$ Robert D. Richards \& Clay Calvert, When Sex and Cell Phones Collide: Inside the Prosecution of a Teen Sexting Case, 32 HAstings Comm. \& ENT. L.J. 1, 17 (2009). The article includes a transcript of the authors’ interview with Alpert and his attorney in question-and-answer format. Id. at 10-34.

${ }^{39} \mathrm{Id}$. at 17.
} 
showed her standing in front of the camera without clothes on. ${ }^{40}$ Unfortunately, Phillip’s relationship with his girlfriend did not last. After quarreling one night, Phillip decided to exact revenge on his girlfriend. ${ }^{41}$ He used the password she had previously shared with him to access her e-mail account. ${ }^{42}$ Phillip then retrieved the nude picture his girlfriend had taken of herself (and had voluntarily sent to him), and sent it to all of her e-mail contacts, totaling about seventy people. ${ }^{43}$

Sending his girlfriend's nude picture to her e-mail contacts without her consent was profoundly unwise. It undoubtedly greatly embarrassed his girlfriend and shocked and surprised the recipients. His actions arguably violated her privacy rights and were actionable as an invasion of her privacy, as this Article discusses below. ${ }^{44}$ While Phillip may deserve some form of punishment, the punishment he received does not fit the “crime.” After his former girlfriend's parents contacted the authorities, Phillip was arrested and threatened with prosecution for 140 counts of child pornography_one count for each "possession” and another for each distribution of the image, applying each of the two counts to the seventy individual recipients. ${ }^{45}$ Prosecutors told him he would spend most of his life in prison if he did not accept a plea. ${ }^{46}$

\footnotetext{
${ }^{40} I d$.

${ }^{41}$ Id. at 8 .

${ }^{42} I d$.

${ }^{43} I d$.

${ }^{44}$ See Part VI, infra, which argues that incidents of sexting in which images are shared without the consent of the subject are actionable under the public disclosure of private fact prong of the common law invasion of privacy tort.

${ }^{45}$ Richards \& Calvert, supra note 38, at 19.

${ }^{46} I d$. at 20.
} 
Faced with the devastating possibility of life in prison, Phillip pled guilty to child pornography charges ${ }^{47}$ He was sentenced to five years probation and is required to register as a sex offender wherever he resides until he turns forty-three years old (and perhaps indefinitely). ${ }^{48}$ His name and face now appear on posters describing him as guilty of child pornography. ${ }^{49}$ Because he was arrested for a felony, his college expelled him and he has been unable to secure employment (prospective employers apparently do not want to hire him because of his criminal record). ${ }^{50}$ Furthermore, Phillip can no longer live with his father because his father's home is too close to the high school Phillip attended, and registered sex offenders cannot live in close proximity to such schools. ${ }^{51}$ In short, Phillip's life was devastated by the consequences of his unwise act and by the state’s decision to charge him under child pornography laws.

Prosecutors throughout the nation have subjected teens who engaged in similar conduct to the draconian regime of state child pornography laws. In April 2009, for example, a fourteenyear-old New Jersey girl was arrested and charged with possession and distribution of child pornography for posting thirty nude pictures of herself on MySpace to share with her boyfriend. ${ }^{52}$ The National Center for Missing and Exploited Children found the photos and

\footnotetext{
${ }^{47} I d$.

${ }^{48}$ Federal law requires states to comply with certain mandates regarding offender registration. The federal Sex Offender Registration and Notification Act, 42 U.S.C. $\S \S 16911-16914$, required states to amend their laws to subject all juveniles over the age of fourteen convicted of applicable child pornography or sex offense charges to the mandate under Megan's Law which requires sex offenders to register for at least ten years and to have their names and pictures displayed on the state's sex offender website.

49 See Sexual Offender/Predator Flyer, FLA. DEP’T OF LAW ENFORCEMENT, http://offender.fdle.state.fl.us/offender/flyer.do?personId=60516 (last visited Sept. 9, 2011).

${ }^{50}$ Richards \& Calvert, supra note 38, at 9.

${ }^{51}$ Id. at 21.

52 See Charles Toutant, Legislation Would Decriminalize 'Sexting' by Teens, N.J. L.J., July 21, 2009; Passaic Teen Faces Child Porn Charges for Posting Nude Pics of Herself on Myspace, NJ.COM (Mar. 26, 2009, 1:35 PM), http://www.nj.com/news/index.ssf/2009/03/passaic_14yearold_arrested_for.html.
} 
informed the local sheriff's department. ${ }^{53}$ In March 2004, a fifteen-year-old girl was arrested for taking nude photographs of herself engaged in various sexual acts and posting them on the Internet. ${ }^{54}$ Prosecutors charged her with sexual abuse of a child, possession of child pornography, and dissemination of child pornography. ${ }^{55}$ In October 2008, a fifteen-year-old girl from Newark, Ohio was charged with felony child pornography for texting nude images of herself to some of her classmates. ${ }^{56}$ If convicted, she may have to register as a sex offender for the rest of her life. ${ }^{57}$ In Greensburg, Pennsylvania, three girls aged fourteen to fifteen texted nude pictures of themselves to three male classmates aged sixteen to seventeen. ${ }^{58}$ School officials seized one of the male students' cell phones for using it in violation of the school's rules and discovered the photos. ${ }^{59}$ The girls were "charged with manufacturing, disseminating, or possessing child pornography, while the boys face[d] charges of possession" of child pornography. ${ }^{60}$ In Virginia, two teenage high school students were charged in 2009 with child pornography and related charges after they solicited nude and semi-nude pictures of younger female students to trade among themselves. ${ }^{61}$ The list goes on.

\footnotetext{
${ }^{53}$ Girl Posts Nude Pics, Is Charged with Kid Porn, MSNBC.COM (Mar. 27, 2009, 9:01 AM), http://www.msnbc.msn.com/id/29912729/.

54 Teen Girl Charged with Posting Nude Photos on Internet, USA TODAY (Mar. 29, 2004, 6:34 PM), http://www.usatoday.com/tech/webguide/internetlife/2004-03-29-child-self-porn_x.htm.

${ }^{55} I d$.

56 See Violet Blue, When Teens Make Their Own Porn, Who’s Being Exploited?, SFGATE.COM (Jan. 29, 2009), http://articles.sfgate.com/2009-01-29/living/17331420_1_child-pornography-boys-face-charges-nude-photographs.

${ }^{57} I d$.

58 See id.

59 See id.

${ }^{60} \mathrm{Id}$. (internal quotation marks omitted).

${ }^{61}$ Bill Starks, Two Spotsylvania Students Arrested for Child Porn, in Latest 'Sexting' Case, 9 NEws Now (Mar. 10, 2009, 6:35 PM), http://www.wusa9.com/news/local/story.aspx?storyid=82608\&catid=188.
} 
In short, many teens in several states are engaging in sexting —as many as fifteen to twenty percent of teens who have a cell-phone, according to the latest studies. ${ }^{62}$ Prosecuting such conduct under criminal child pornography laws is misguided, unconstitutional, and may harm the very people the laws were designed to protect.

\section{Child Pornography Laws and the First Amendment}

Currently enacted child pornography laws, at both the federal and state level, generally do not exempt cases of sexting from their reach. However, an analysis of the Supreme Court's child pornography jurisprudence shows that applying such laws to typical incidents of sexting is unconstitutional and inconsistent with the government's interests underlying such laws.

Generally, child pornography laws punish the possession, creation, distribution, and receipt of visual depictions of children engaged in sexually explicit conduct. Such laws typically apply across the board to minors and do not exempt minors who are near the age of majority or, indeed, over the legal age to consent to sexual relations. ${ }^{63}$ The term "minor" in child pornography laws includes individuals up to age eighteen, although some state laws specify a different age range. In recent years, laws addressing child pornography have become increasingly harsh and expansive in their reach, especially at the federal level. ${ }^{64}$ This Article reviews the contours of state and federal child pornography laws and examines the Supreme Court jurisprudence in this area, concluding that applying these laws to instances of sexting does not withstand constitutional scrutiny.

\footnotetext{
62 See supra text accompanying notes 6-8.

63 See infra text accompanying notes 66-67.

${ }^{64}$ Indeed, the federal Commission on Pornography (unsuccessfully) recommended increasing the age of majority for child pornography laws from eighteen to twenty-one. See ATTORNEY GENERAL's COMMISSION ON PORNOGRAPHY, FINAL REPORT 623-28 (1986).
} 


\section{A. The Contours of Federal Child Pornography Laws}

Congress undertook its first effort to outlaw child pornography with the passage of the Protection of Children Against Sexual Exploitation Act of 1977. ${ }^{65}$ This Act defines child pornography as "any visual depiction . . . of sexually explicit conduct” by a minor ${ }^{66}$ and defines “minor" to include all those under eighteen years of age. ${ }^{67}$ In response to the increased use of personal computers to access sexually explicit content, Congress moved to expand the Act's reach and in 1988 passed amendments to the Act which included criminalizing the transmission of child pornography "by any means including by computer." 68

The Child Pornography Prevention Act of 1996 (CPPA), provisions of which Ashcroft v. Free Speech Coalition struck down, ${ }^{69}$ revised and extended the behavior prohibited by the Act. CPPA made it a crime to transport, distribute, or receive "any visual depiction" that "involves the use of a minor engaging in sexually explicit conduct."70 The Act also criminalized the possession of computer disks containing three or more images of child pornography. ${ }^{71} \mathrm{CPPA}$ extended the federal prohibition of child pornography to sexually explicit images that appear to depict minors but were produced without real children, as well as material promoted or pandered so as to convey the impression that it involves minors, regardless of whether it actually involves

6518 U.S.C. §§ 2251-2259 (2006).

${ }^{66}$ Id. § 2256(8). Sexually explicit conduct is defined to include: “actual or simulated (i) sexual intercourse, including genital-genital, oral-genital, anal-genital, or oral-anal, whether between persons of the same or opposite sex; (ii) bestiality; (iii) masturbation; (iv) sadistic or masochistic abuse; or (v) lascivious exhibition of the genitals or pubic area of any person.” Id. § 2256(2)(B).

${ }^{67}$ Id. $\S 2256(1)$.

${ }^{68}$ Child Protection and Obscenity Enforcement Act of 1988, Pub. L. No. 100-690, § 7511(b), 102 Stat. 4485 , 4485 (1988) (codified as amended at 18 U.S.C. § 2252(a) (2006)).

69535 U.S. 234, 258 (2002).

70 See Child Pornography Prevention Act of 1996, 18 U.S.C. § 2252(a)(1)-(2) (2006).

${ }^{71} 18$ U.S.C. § 2252A. 
minors. In 1998, the Protection of Children from Sexual Predators Act modified the federal possession requirement to prohibit possession of a computer disk that contains a single image of child pornography (revising the three-image requirement in CPPA). ${ }^{72}$ After portions of the CPPA were struck down in Ashcroft v. Free Speech Coalition, Congress went back to the drawing board in an attempt to remedy the constitutional defects identified by the Court, and passed the Prosecutorial Remedies and Other Tools to end the Exploitation of Children Today Act of 2003 (the PROTECT Act). ${ }^{73}$ This Act redefined and narrowed the pandering and solicitation provisions of CPPA to punish only those who actually believe, or intend others to believe, that the subjects of the sexually oriented material at issue are real children. ${ }^{74}$ The Supreme Court upheld these provisions of the PROTECT Act in United States v. Williams. ${ }^{75}$

Punishment of child pornography under federal law is subject to severe penalties, including a mandatory minimum sentence of five years in prison for any first offense involving trafficking. ${ }^{76}$ Additionally, those convicted of child pornography are typically required to register as sex offenders. ${ }^{77}$ Federal law provides for severe maximum penalties as well, including a maximum punishment of twenty years for a first offense ${ }^{78}$ and double that amount if the defendant has a qualifying prior conviction or if the offense involved hard-core child pornography. ${ }^{79}$ The federal government has aggressively prosecuted child pornography offenses

\footnotetext{
${ }^{72}$ Id. § 2252A(a)(5).

73117 Stat. 650 (2003).

${ }^{74}$ See id.

75553 U.S. 285 (2008).

${ }^{76}$ See 18 U.S.C. § 2252(b)(1)-(2).

${ }^{77}$ See 42 U.S.C. § 16913 (sex offender registration).

7818 U.S.C. § 2252(b)(1).

${ }^{79}$ Id. § 2252(b)(2).
} 
under these statutes. For example, over 1,500 defendants faced child pornography and related offenses in 2005. ${ }^{80}$ In 2007, the Justice Department launched Project Safe Childhood and cracked down even more heavily on child pornography and related offenses. ${ }^{81}$

To the extent that these federal child pornography laws are applied to acts of actual child pornography (typically involving possession, creation, or distribution of images of young children by older male sexual predators, as well as involving or constituting sexual abuse of children), these harsh penalties are appropriate. As the Supreme Court recognized, "[t]he sexual abuse of a child is a most serious crime and an act repugnant to the moral instincts of a decent people." ${ }^{82}$ However, to the extent that such laws are extended to incidents of teen sexting, the penalties are disproportionately harsh and unconstitutional as applied. Federal child pornography laws provide no exception for sexually explicit images voluntarily created and shared by older teenagers, despite the fact that under federal law the teenagers may legally consent to engage in sexual activity. ${ }^{83}$ Consequently, an individual can legally consent to engage in sexual activity, but face severe criminal punishment for depicting such activity. Protecting sexual activity while criminalizing the depiction and communication of depictions of that activity leads to an anomalous result and presents First Amendment problems.

\section{B. State Child Pornography Laws}

The vast majority of states also have child pornography laws that regulate the production, distribution, or possession of child pornography. Like Congress, many state legislatures have

\footnotetext{
${ }^{80}$ See U.S. Dep’t of Justice, Fact Sheet: Department of Justice Project Safe Childhood Initiative, (Feb. 15, 2006), http://www.usdoj.gov/opa/pr/2006/February/06_opa_081.html.

${ }^{81}$ See, e.g., Jerry Markon, Crackdown on Child Pornography, WASH. Post, Dec. 15, 1997, at A1.

${ }^{82}$ Ashcroft v. Free Speech Coalition, 535 U.S. 234, 244 (2002).

${ }^{83}$ See 18 U.S.C. § 2243(a) (age of consent in the federal maritime and territorial jurisdiction is sixteen).
} 
amended their statutes to apply to computer, electronic, or digital images. ${ }^{84}$ In fashioning their child pornography laws, the majority of states (thirty-two) define a child as any person under the age of eighteen, ${ }^{85}$ notwithstanding the fact that the vast majority of such states also fix the age of consent to legally engage in sexual activity at sixteen. ${ }^{86}$ In contrast, three states define child under their child pornography laws as anyone under the age of seventeen, ${ }^{87}$ three other states define child as anyone under the age of sixteen, ${ }^{88}$ others provide variable definitions of minor, ${ }^{89}$ and the remaining do not explicitly define the age of a "minor" or "child."90 Yet, other states,

${ }^{84}$ See Karl A. Menninger, II, Cyberporn: Transmission of Images by Computer as Obscene, Harmful to Minors or Child Pornography, 61 AM. JUR. PROOF OF FACTS 3d 51, 87 (explaining that "state laws prohibiting child pornography have phrases or terms clearly including computer-generated images”); see also id. nn.17-24.

${ }^{85}$ These states are Alaska, Arizona, California, Colorado, Florida, Georgia, Hawaii, Idaho, Illinois, Indiana, Iowa, Kansas, Maine, Massachusetts, Michigan, Minnesota, Mississippi, Nebraska, New Hampshire, New Mexico, North Carolina, North Dakota, Oklahoma, Oregon, Pennsylvania, Rhode Island, Texas, Utah, Virginia, West Virginia, Wisconsin, and Wyoming. See Nat'l Dist. Attorney's Ass'n, Nat'l Ctr. for Prosecution of Child Abuse, Child Pornography Distribution and Promotion Statutes, available at http://www.ndaa.org/pdf/Child\%20Pornography\%20Distribution\%20Statutes\%203-2010.pdf (last updated June 2010).

${ }^{86}$ Thirty-four states set the age of consent- the minimum age at which an individual can legally consent to engage in sexual intercourse under any circumstances-at sixteen years of age, while another six set the age of consent at seventeen years of age. LeWin Group, U.S. DeP'T OF HeAlth \& Human SERVS., STAtutory RaPe: A GUIDE TO STATE LAWS AND REPORTING REQUIREMENTS 5 (2004), available at http://aspe.hhs.gov/hsp/08/SR/StateLaws/report.pdf.

${ }^{87}$ These states are Alabama, Arkansas, and Louisiana. Child Pornography Distribution and Promotion Statutes, supra note 85 , at $6,10,63$.

${ }^{88}$ These states are Connecticut, Montana, and Vermont. Id. at 23-24, 89-90, 139.

${ }^{89}$ These states are Delaware, Ohio, South Carolina, South Dakota, Tennessee, and Washington. Id.

${ }^{90}$ Other state codes provide different definitions of minor for different sections. Maryland's code does not define the term minor in § 11-207 (child pornography) but § 11-208 (possession of visual representation of child under 16 engaged in certain sexual acts) defines minor as anyone under sixteen. MD. CODE ANN., CRIM. LAW §§ 11207, 11-208 (LexisNexis Supp. 2011). It is unclear whether this definition is intended to apply to the section preceding it. Missouri defines a child as anyone under fourteen, but child pornography includes "[a]ny obscene material or performance depicting sexual conduct, sexual contact, or a sexual performance, as these terms are defined in section 556.061, RSMo, and which has as one of its participants or portrays as an observer of such conduct, contact, or performance a minor under the age of eighteen.” Mo. ANN. STAT. § 573.010(2)(a) (West 2011). In Nevada, minor is not explicitly defined either, but the punishments vary based on the age of the child involved in the pornography. NEV. REV. STAT. ANN. § 200.750 (LexisNexis 2006) (“A person punishable pursuant to NRS 200.710 or 200.720 shall be punished for a category A felony by imprisonment in the state prison: 1 . If the minor is 14 years of age or older, for life with the possibility of parole, with eligibility for parole beginning when a minimum of 5 years has been served, and shall be further punished by a fine of not more than $\$ 100,000$. 2. If the minor is less than 14 years of age, for life with the possibility of parole, with eligibility for parole beginning when a minimum of 10 years has been served, and shall be further punished by a fine of not more than $\$ 100,000$.”). New Jersey’s 
while defining "minor" broadly as anyone under eighteen, provide for enhanced punishment if the minor involved is below a certain age. ${ }^{91}$ Some states provide for an affirmative defense if the defendant is not much older than the minor involved, ${ }^{92}$ while other states enhance penalties where the adult is significantly older than the minor involved. ${ }^{93}$ In contrast, some states' child pornography laws provide for varying penalties that depend on the age of the minor involved. ${ }^{94}$ State laws also vary in terms of their reach, with some, like Pennsylvania, extending broadly to depictions of "nudity ... depicted for the purpose of sexual stimulation or gratification of any person who might view such depiction," ${ }^{95}$ while other states provide for narrower definitions of prohibited expression. ${ }^{96}$

As applied to instances of sexting, the vast majority of state laws—like comparable federal laws—-provide no exceptions for sexually explicit images that are voluntarily created and shared by teens, despite the fact that under these state laws, some teens are old enough to legally consent to engage in sexual activity. As under the federal law, this means that an individual can

statutes are similarly ambiguous, with some sections defining a minor as anyone under eighteen and other sections defining a minor as anyone under sixteen. In New York, some provisions apply to minors under sixteen, others apply to minors under seventeen.

${ }^{91}$ For example, in Texas, sexual conduct with a minor under eighteen is a second degree felony. If the minor is under fourteen, the felony becomes a first degree felony. TEX. PENAL CODE ANN. § 43.25(c) (West 2011). Virginia also defines a minor as anyone under the age of eighteen, but also enhances penalties where the minor is less than fifteen. VA. CODE ANN. § 18.2-374.1(C1) \& (C2) (2009).

${ }^{92}$ For example, Texas allows an affirmative defense if the defendant is not more than two years older than the minor involved. TEX. PENAL CODE § 43.25(f)(3).

${ }^{93}$ Virginia, for example, enhances penalties where the adult is more than seven years older than the minor involved. VA. CODE ANN. § 18.2-374.1(C1) \& (C2) (2009).

94 See, e.g., KY. REV. STAT. ANN. § 531.320(2)(a) \& (2)(b) (LexisNexis 2008) ("Promoting a sexual performance by a minor is: (a) A Class $C$ felony if the minor involved in the sexual performance is less than eighteen (18) years old at the time the minor engages in the prohibited activity; (b) A Class B felony if the minor involved in the sexual performance is less than sixteen (16) years old at the time the minor engages in the prohibited activity.”).

\footnotetext{
9518 PA. CONS. STAT. ANN. § 6312 (2009).

${ }^{96}$ See supra text accompanying notes 90-94.
} 
legally consent to engage in sexual activity, yet face severe criminal punishment for creating, possessing, or sharing an image of herself engaged in such activity. Once again, this presents serious First Amendment problems.

To make matters worse, some states have recently specifically amended their child pornography and related laws to expressly cover instances of sexting. Lawmakers in eleven states introduced legislation in 2009 aimed at deterring teens from sexting. ${ }^{97}$ Colorado, for example, added "text messages" to the definition of the means to commit "computer dissemination of indecent material to a child" ${ }^{98}$ so as to encompass sexting within the reach of this law. Following this trend, Utah recently enacted legislation providing for penalties for minors who distribute pornographic material or who deal in material harmful to a minor. ${ }^{99}$ In summary, sexting appears to be within the reach of most state child pornography laws, and some states are expressly revising their laws to make clear that they encompass acts of sexting.

\section{Child Pornography Jurisprudence}

First Amendment law regarding child pornography has evolved along a somewhat separate course than the law governing obscenity generally. While both areas involve sexually themed works, the Supreme Court has articulated a separate jurisprudence governing the

\footnotetext{
${ }^{97}$ See Nat'l Conference of State Legislatures, 2009 "Sexting” Legislation, http://www.ncsl.org/default.aspx?tabid=17756 (last updated Sept. 1, 2010).

${ }^{98}$ See COLO. REv. STAT. § 13-21-1002(1) (2011) (defining computer dissemination of indecent material to a child as "[a] person commits computer dissemination of indecent material to a child when: (a) Knowing the character and content of the communication which, in whole or in part, depicts actual or simulated nudity, or sexual conduct, as defined in section 19-1-103(97), C.R.S., the person willfully uses a computer, computer network, telephone network, data network, or computer system allowing the input, output, examination, or transfer of computer data or computer programs from one computer to another or a text-messaging or instant-messaging system to initiate or engage in such communication with a person he or she believes to be a child; and (b) By means of such communication the person importunes, invites, entices, or induces a person he or she believes to be a child to engage in sexual contact, sexual intrusion, or sexual penetration with the person, or to engage in a sexual performance or sexual conduct, as defined in section 19-1-103(97), C.R.S., for the person's benefit.”).
}

${ }^{99}$ See H.B. 14, 2009 Gen. Sess. (Utah 2009). 
regulation of sexually themed works with minors as subjects, which constitutes a "related and overlapping category of proscribable speech.”100

The law of obscentiy governs sexually themed works involving subjects of all agesadults and minors. Indeed, although incidents of sexting have been the subject of child pornography prosecutions, such images might also constitute obscene works under federal or state law. For much of the twentieth century, the Supreme Court struggled to articulate a coherent and workable set of guidelines for distinguishing protected sexually themed expression protected by the First Amendment from sexually theme expression that constitutes obscenity. Ultimately, in Miller v. California, the Supreme Court fashioned a set of guidelines for the regulation of sexually themed works. ${ }^{101}$ The three-prong Miller test requires a consideration of: (1) whether "the average person, applying contemporary community standards" would find that the work, taken as a whole, appeals to the prurient interest; (2) whether the work depicts or describes, in a patently offensive way, sexual conduct specifically defined by the applicable state law; and (3) whether the work, taken as a whole, lacks serious literary, artistic, political, or scientific value. $^{102}$

The Miller test provides important safeguards for sexually themed speech. Miller first makes clear that obscenity is determined using a local, community standard. ${ }^{103}$ Specifically, the applicable standard is that of the average member of the community, applying contemporary community standards to assess whether the expression at issue, taken as a whole, appeals to the

100 United States v. Williams, 553 U.S. 285, 288 (2008).

101413 U.S. 15, 24 (1973). These guidelines remain the current standard. See, e.g., Jenkins v. Georgia, 418 U.S. 153, 157 (1974); Pope v. Illinois, 481 U.S. 497, 500-01 (1987).

${ }^{102} I d$.

103 Miller, 413 U.S. at 30-32. 
prurient interest. ${ }^{104}$ Second, Miller requires that, to regulate obscene content, a regulator (whether the federal, state, or local government) must specifically define which descriptions or depictions of specific sexual acts may be deemed patently offensive under contemporary community standards. ${ }^{105}$ This requirement reduces the potential for vagueness within obscenity statutes. ${ }^{106}$ Determining whether a work is patently offensive, like determining whether a work appeals to the prurient interest, is judged under the standard of the average member of the local community. ${ }^{107}$ The third prong of Miller provides that judges retain the power to determine whether sexually themed speech has redeeming serious social value (i.e., literary, artistic, political, or scientific value) and, therefore, whether such speech is protected by the First Amendment regardless of its assessment by local communities. ${ }^{108}$ Because this determination is ultimately to be made by courts and not jury members, this "savings clause" provides a judicial check on local communities' power to determine what sexually themed expression is unprotected by the First Amendment. As the Supreme Court has explained, "the serious value requirement 'allows appellate courts to impose some limitations and regularity on the definition [of obscenity] by setting, as a matter of law, a national floor for socially redeeming value.’”109

\footnotetext{
${ }^{104}$ Id. at $30-31$.

${ }^{105}$ See id. at 24-25.

${ }^{106}$ See Reno v. ACLU, 521 U.S. 844, 873 (1997).

${ }^{107}$ See Ashcroft v. ACLU, 535 U.S. 564, 576 n.7 (2002) (“[T]he 'patently offensive' prong of the test is also a question of fact to be decided by a jury applying contemporary community standards.").

${ }^{108}$ See, e.g., Jenkins v. Georgia, 418 U.S. 153 (1974) (reversing jury verdict where film in question was not patently offensive under the Miller standard).

${ }^{109}$ See Ashcroft v. ACLU, 535 U.S. at 579 (emphasis in original). Thus, even if a less "tolerant” community made the determination that a certain edition of The Joy of Sex was obscene and unprotected by the First Amendment, Miller requires that such determinations be second-guessed by the judicial branch, which has the responsibility for applying this Miller savings clause to declare that the expression at issue nonetheless has serious redeeming social value and is therefore protected by the First Amendment. Accordingly, despite the fact that a local jury in Georgia, applying its state obscenity statute, determined that the Academy Award-winning film Carnal Knowledge appealed to the prurient interest and described sexually conduct in a patently offensive manner, the court in that case enjoyed and exercised the power to determine that the work nonetheless enjoyed serious literary value.
} 
A decade after it set forth the Miller standard governing obscene works generally, the Supreme Court articulated a separate test for sexually themed works depicting minors, which are afforded less First Amendment protection. For works involving child pornography, New York $v$. Ferber fashioned a separate test that did not include the speech-protective elements of the Miller test. ${ }^{110}$ Since its Ferber decision in 1982, the Court has continued to advance this separate but related jurisprudence for sexually themed works involving minors, in cases such as Osborne v. Ohio, ${ }^{111}$ Ashcroft v. Free Speech Coalition, ${ }^{112}$ and recently in United States v. Williams. ${ }^{113}$

In Ferber, the Supreme Court made clear that First Amendment protection for sexually themed works depicting minors is not governed by the same test as obscene works generally. ${ }^{114}$ Ferber involved the constitutionality of a New York statute that criminalized the promotion of a “sexual performance by a child.” 115 The statute defined “child” as anyone fifteen years of age or younger, ${ }^{116}$ and included a detailed and specific definition of "sexual performance.”117 Paul Ferber was the proprietor of a Manhattan bookstore specializing in sexually themed works and sold two films to an undercover police officer that depicted young boys masturbating. ${ }^{118}$ Ferber

The court was therefore able to rescue the film from the jury's classification of it as obscene and unprotected by the First Amendment. See Jenkins, 418 U.S. at 153.

${ }^{110}$ New York v. Ferber, 458 U.S. 747 (1982).

111495 U.S. 103 (1990).

112535 U.S. 234 (2002).

113553 U.S. 285 (2008).

${ }^{114}$ Ferber, 458 U.S. at 764.

${ }^{115}$ Id. at 750 (citing N.Y. PENAL LAW § 263 (McKinney 1980)).

${ }^{116}$ Id. at 751 (The statute defined sexual performance as "any performance or part thereof which includes sexual conduct by a child less than sixteen years of age.”) (quoting N.Y. PENAL LAW § 263.00(1)).

${ }^{117}$ Id. (The statute defined sexual conduct to include "actual or simulated sexual intercourse, deviate sexual intercourse, sexual bestiality, masturbation, sado-masochistic abuse, or lewd exhibition of the genitals.”) (quoting N.Y. PENAL LAW § 263.00(3)).

${ }^{118}$ Id. at 751-52. 
challenged the constitutionality of the New York statute, claiming that the works in question were governed by the Miller obscenity standard, and that the state had no power to criminalize depictions of sexual conduct involving minors that were not legally obscene under Miller. ${ }^{119}$ The Supreme Court disagreed.

First, the Court rejected Ferber's argument that sexual works involving children can only be banned if the works are obscene under the Miller standard. ${ }^{120}$ Because the "prevention of sexual exploitation and abuse of children constitutes a government objective of surpassing importance,” the state's interest in preventing these harms is distinct from the state's interest in preventing offense from viewing obscene material that the Court credited in Miller. ${ }^{121}$ The Court observed that the Miller standard, which recognizes the state's interest in protecting the "sensibilities of unwilling recipients" from offense brought about by exposure to pornographic materials, "does not reflect the state's particular and more compelling interest in prosecuting those who promote the sexual exploitation of children." ${ }^{122}$ While Miller primarily concerns offenses based on unwilling exposure to sexually themed expression generally, the state's interest in regulating child pornography primarily centers around drying up the market for child pornography and preventing sexual exploitation and abuse of children, by punishing those who commercially promote material that involves the sexual exploitation of children-which is itself a crime. To remove the economic incentive for commercial exploitation of such works and to protect children from sexual exploitation, the Supreme Court recognized that states must be

\footnotetext{
${ }^{119}$ Id. at $760-61$.

${ }^{120} \mathrm{Id}$.

${ }^{121}$ Id. at 757.

${ }^{122}$ Id. at 761 (emphasis added).
} 
permitted to regulate materials that involve actual sexual exploitation of children under a standard different than that articulated in Miller.

Under the standard articulated in Ferber, states may prohibit the promotion of sexual conduct involving a minor in order to dry up the market for the sexual exploitation and abuse of children if (1) such conduct is specifically and narrowly defined by the applicable state law, and (2) the work visually depicts sexual conduct by children at or below a specified age (which, in the case of the New York statute, was fifteen years of age). ${ }^{123}$ The Court was careful to emphasize, however, that depictions of nudity, without more, could not be constitutionally prohibited. ${ }^{124}$

Yet, because the state's interest in drying up the material for the sexual exploitation of children is stronger than its interest in protecting adults from being offended by unwilling exposure to obscene works, the safeguards applicable to sexually themed works depicting adults generally do not extend to sexually themed works depicting minors. First, to be proscribable under Ferber, the work need not be "taken as a whole," nor must the work "appeal to the prurient interest of the average person” or be “patently offensive.” 125 Furthermore, under Ferber’s test, it is apparently irrelevant whether the material has "serious literary, artistic, political or social value» ${ }^{126}$ when determining whether a work is illegal child pornography. The Court has further distinguished child pornography from obscenity in its decisions regarding private possession. While adults enjoy the right to possess even obscene works in the privacy of their own homes

\footnotetext{
${ }^{123} I d$. at 764 .

${ }^{124}$ Osborne v. Ohio, 495 U.S. 103, 112-14 (1990) (citing Ferber for the proposition that "depictions of nudity, without more, constitute [First Amendment] protected expression" and holding that the Ohio Supreme Court's limiting construction of the state statute at issue in that case "avoided penalizing persons for viewing or possessing innocuous photographs of naked children”).

${ }^{125}$ Ferber, 458 U.S. at 761.

${ }^{126} I d$.
} 
under Stanley v. Georgia, ${ }^{127}$ the Court made clear in Osborne v. Ohio that private possession of child pornography is not similarly protected. ${ }^{128}$ Because the state has a compelling interest in "stamp[ing] out this vice at all levels in the distribution chain" and because such images, even if privately possessed, “permanently record the victim’s abuse,” the private possession of child pornography is not constitutionally protected. ${ }^{129}$

The Supreme Court further articulated its child pornography jurisprudence in evaluating the constitutionality of the federal Child Pornography Prevention Act of 1996 (CPPA). ${ }^{130}$ This Act extended the federal prohibition against child pornography to sexually explicit images that appear to depict minors but that were produced without actual minors and to material that was promoted so as to convey the impression that it involved minors, even if it actually did not. ${ }^{131}$ Extending the definition of child pornography to sexually explicit depictions that appear to be of a minor, the CPPA intended to capture a range of depictions involving "virtual” child pornography that include computer-generated images of minors, as well as images of actual youthful-looking adults engaging in sexually explicit conduct. Second, the CPPA extended the definition of child pornography to computer-modified images of real children that are made to appear as if the children are engaged in sexual activity, even though no minors were actually engaged in sexual activity. ${ }^{132}$ Third, the CPPA extended the definition of child pornography to

127 Stanley v. Georgia, 394 U.S. 557, 568 (1969) (holding that the "mere private possession of obscene material” is not a crime).

128 Osborne, 495 U.S. at 111 (holding that “Ohio may constitutionally proscribe the possession and viewing of child pornography”).

${ }^{129}$ Id. at $110-11$.

${ }^{130}$ See 18 U.S.C. §§ 2251-2260A.

13118 U.S.C. § 2256 (2006).

132 See id. § 2256(8)(C) (covering material that has been "created, adapted, or modified to appear that an identifiable minor is engaging in sexually explicit conduct”). 
include any sexually explicit image that is "advertised, promoted, presented, described, or distributed in such a manner that conveys the impression” that it depicts a minor engaging in sexually explicit conduct. ${ }^{133}$ This provision was intended to encompass sexually explicit images that are intentionally "pandered as" child pornography, ${ }^{134}$ regardless of whether any actual children were depicted in such images. The Act defined minor as anyone under the age of eighteen, ${ }^{135}$ an age that is above the legal age for marriage in virtually every state and above the age at which persons may consent to sexual relations in most states. ${ }^{136}$ CPPA also provided for severe penalties for violations of these provisions, including prison terms of up to fifteen years for first-time offenders and up to thirty years for repeat offenders. ${ }^{137}$ The Free Speech Coalition, a trade association for the adult entertainment industry and artists specializing in nude and erotic images, challenged several of the definitional changes enacted by the CPPA. ${ }^{138}$ The challengers asserted that because the statute banned images that do not involve actual children engaging in sexual performances, it swept too broadly and infringed their First Amendment rights. ${ }^{139}$ The Supreme Court agreed.

\footnotetext{
${ }^{133} I d . \S 2256(8)(\mathrm{D})$.

${ }^{134}$ Ashcroft v. Free Speech Coalition, 535 U.S. 234, 242 (2002).

13518 U.S.C. § 2256(1).

${ }^{136}$ See id. § 2243(a) (age of consent in the federal maritime and territorial jurisdiction is sixteen); WILLIAM N. ESKRIDGE, JR. \& NAN D. HUNTER, SEXUALITY, GENDER, AND THE LAW 1021-22 (1997) (listing the age of consent for engaging in sexual activity in each state, which shows the age is sixteen or younger in thirty-nine states and the District of Columbia); NATIONAL SURVEY OF STATE LAWs 384-88 (Richard A. Leiter ed., 3d ed. 1999) (stating forty-eight states permit sixteen-year-olds to marry with parental consent).
}

13718 U.S.C. § 2252A(b)(1) (Supp. II 1997). The current statute provides similarly harsh penalties. See 18 U.S.C. § 2252A(b)(1)-(3) (2006) (providing up to fifteen years for first-time offenders and up to forty years for repeat offenders).

${ }^{138}$ Because the second extension, involving morphed images, applied to images of actual children, whose interests were implicated by the morphing of their images to make it appear that they were engaged in sexual acts, this extension was not challenged by the plaintiffs in this case.

${ }^{139}$ Free Speech Coalition, 535 U.S. at 243. 
The Court in Free Speech Coalition reviewed and clarified its holding in Ferber by explaining that Ferber stood for the proposition that the distribution, sale, and production of child pornography could be banned because such acts “were 'intrinsically related' to the sexual abuse of children in two ways." 140 Because the commercial trafficking in child pornography was an economic motive for its production, "the most expeditious . . . method of law enforcement may be to dry up the market for this material by imposing severe criminal penalties on persons selling, advertising, or otherwise promoting the product." ${ }^{141}$ Further, the Ferber Court held that because pornographic material depicting actual children constituted a permanent record of the child's abuse, the continued circulation of the material would harm the child who participated. ${ }^{142}$ The Court explained that under either of these rationales, the images had a "proximate link to the crime from which it came" 143 and went on to hold that "the creation of the speech is itself the crime of child abuse."144 In contrast, the Court stated that the first provision of the CPPA challenged by Free Speech Coalition, which prohibited the creation of sexually explicit images using youthful-looking adults or computer-generated images of (imaginary) minors, restricted “speech that records no crime and creates no victims by its production." 145 The Court therefore emphasized that the state's interest in regulating child pornography is primarily one of drying up the market for depictions of child sexual abuse involving actual children-activity that involves an actual crime. ${ }^{146}$

\footnotetext{
${ }^{140} I d$. at 249.

${ }^{141}$ Id. at 249-50 (quoting Ferber, 458 U.S. at 760).

${ }^{142} \mathrm{Id}$. at 249.

${ }^{143} \mathrm{Id}$. at 250.

${ }^{144}$ Id. at 254.

${ }^{145} \mathrm{Id}$. at 250.

${ }^{146} I d$. at 254.
} 
The Court next examined the provision of the statute prohibiting sexually explicit materials that "convey the impression” of depicting minors if the material was promoted or pandered" in such a way as to suggest that it involved actual minors, ${ }^{147}$ even if it did not. Under this provision, it is irrelevant whether the sexually explicit images actually depict any minors. Even if a work contains no sexually explicit scenes involving minors, it could still constitute child pornography that could be banned if the promotion of the work conveys the impression that it involves actual minors. ${ }^{148}$ In evaluating this provision, the Court acknowledged that its prior precedent recognized that the "pandering” or commercial exploitation of a work factors in the issue of whether the work constituted illegal obscenity. ${ }^{149}$ In Ginzburg v. United States, for example, the Court explained that "in close cases, evidence of pandering may be probative with respect to the nature of the material in question and thus satisfy the [obscenity] test.”150 However, the Court in Free Speech Coalition emphasized that the challenged prong of CPPA impermissibly went beyond Ginzburg's pandering rationale to criminalize works even absent a context of "commercial exploitation."151 The majority reasoned that this provision of CPPA went far beyond prohibiting commercial exploitation because it classified materials falling within this provision as "tainted and unlawful in the hands of all who receive it" simply because the materials were "described or pandered as child pornography by someone earlier in the distribution chain.”152 Possession of such material would constitute a crime, even if the material contained no sexual performance by a minor, so long as someone earlier in the distribution chain

${ }^{147}$ Id. at 242 (citing 18 U.S.C. § 2256(8)(D) (1994)).

${ }^{148} I d$. at 257.

${ }^{149}$ Id. at $257-58$.

150383 U.S. 463, 474 (1966).

151535 U.S. at 258.

${ }^{152} I d$. 
had promoted the material as containing such a sexual performance. This provision had the effect of criminally prohibiting the mere possession of sexual explicit materials, regardless of whether they contain sexual performances by a minor. As a result, the Court had little difficulty in finding this provision unconstitutional.

Taken together, Ferber and Free Speech Coalition make clear that the state has a compelling interest in preventing the sexual abuse of children and that this interest may constitutionally be advanced by targeting those who engage in the commercial exploitation of images involving actual sexual abuse of children or that otherwise have a "proximate link" to the crime of sexual exploitation or abuse of children. ${ }^{153}$ The Court emphasized the interest of prosecuting those who commercially promote or are otherwise involved in the sexual exploitation and abuse of children as well as drying up the market for such exploitation and abuse. ${ }^{154}$ Importantly, the Court also made clear that where the content in question is not a product of sexual abuse or proximately linked to the sexual abuse and exploitation of children (nor legally obscene under Miller), such content enjoys full First Amendment protection. ${ }^{155}$

After the Court struck down provisions of the CPPA, Congress went back to the drawing board and attempted to remedy the constitutional defects identified by the Court-in particular, in CPPA's pandering provision. The result was the Prosecutorial Remedies and Other Tools to end the Exploitation of Children Today Act of 2003 (the PROTECT Act), which set forth a revised "pandering and solicitation” provision. ${ }^{156}$ In United States $v$. Williams, Michael

153 See id. at 250.

154 See id. at 254.

155 See id. at 251 (Ferber made clear that "where the speech is neither obscene nor the product of sexual abuse, it does not fall outside the protection of the First Amendment.”).

156 See Pub. L. No. 108-21, § 503, 117 Stat. 650, 680 (2003) (codified as amended at 18 U.S.C. $\S 2252 \mathrm{~A}(\mathrm{a})(3)(\mathrm{B})(2006))$. The revised pandering provision applies to any person who knowingly "advertises, 
Williams challenged his conviction for pandering under this provision of the Act, codified at 18 U.S.C. § 2252A. ${ }^{157}$ The Court rejected his challenge and upheld the provision.

The Court first acknowledged that this section, which prohibits offers to provide and requests to obtain child pornography, does not require the actual existence of child pornography. ${ }^{158}$ Rather, it "bans the collateral speech that introduces such material into the child-pornography distribution network," ${ }^{159}$ which is typically (but not exclusively) a commercial market. Although this section does not require the actual existence of child pornography, the Court nonetheless held that speech falling within the scope of § 2252A could be banned on the ground that "offers to engage in illegal transactions," like the exchange of child pornography, "are categorically excluded from First Amendment protection." ${ }^{160}$ Because an offer to provide or a request to receive child pornography is in fact an offer to engage in an illegal transaction, this collateral speech could be banned so long as the speaker believes, or intends the listener to believe, that the subject of the proposed transaction involves real children. ${ }^{161}$

Several important lessons for the current controversies surrounding sexting may be drawn from the Supreme Court’s child pornography jurisprudence. First, the Court has focused

promotes, presents, distributes, or solicits . . . any material or purported material in a manner that reflects the belief, or that is intended to cause another to believe, that the material or purported material is, or contains” a visual depiction of actual minors engaging in sexually explicit conduct. The Act also provides an appropriately detailed and narrow definition of "sexually explicit conduct," which includes “actual or simulated-(i) sexual intercourse, including genital-genital, oral-genital, anal-genital, or oral-anal, whether between persons of the same or opposite sex; (ii) bestiality; (iii) masturbation; (iv) sadistic or masochistic abuse; or (v) lascivious exhibition of the genitals or pubic area of any person.” See id. § 502(b), 117 Stat. at 678-79 (codified as amended at 18 U.S.C. § 2256(2)(A)).

\footnotetext{
157553 U.S. 285, 292 (2008).

${ }^{158} I d$. at 293.

${ }^{159}$ Id. at 288.

${ }^{160} \mathrm{Id}$. at 297.

${ }^{161}$ Id. at 293.
} 
primarily on the harm that arises from transactions in content integral to the crimes of sexual exploitation and abuse of children. Second, the Court has focused on the commercial or transactional nature of the conduct at issue. In the child pornography context, the Court has recognized in particular the government interest in drying up the commercial. or transactional, ${ }^{162}$ market for child pornography. This emphasis on the market for child pornography echoes the Court's emphasis in the obscenity context, in which the Court has made clear that criminal prohibitions on noncommercial sexually themed speech are unconstitutional. ${ }^{163}$ Third, the Court has explained that depictions of nudity alone—even those involving minors—cannot form the sole basis of a child pornography prosecution. Fourth, the Court has been critical of attempts to criminalize the mere depiction of teens engaged in sexual activity—especially when those depicted are at or near the age at which they can legally consent to have sex. The Court has been critical of attempts to increase the statutory age of "child" for precisely this reason. In criticizing CPPA's extension of the definition of minor to include all those who are or appear to be seventeen years of age or younger, the Supreme Court explained that "the statute proscribes the visual depiction of an idea — that of teenagers engaging in sexual activity—-that is a fact of modern society and has been a theme in art and literature throughout the ages.”164 The Court observed that the age established by the CPPA was higher than the legal age at which persons

${ }^{162}$ As the Court explained in Williams,

To be clear, our conclusion that all the words in this list relate to transactions is not to say that they relate to commercial transactions. One could certainly 'distribute' child pornography without expecting payment in return. Indeed, in much Internet file sharing of child pornography each participant makes his files available for free to other participants - as Williams did in this case .... To run afoul of the statute, the speech need only accompany or seek to induce the transfer of child pornography from one person to another.

553 U.S. 285, 295 (2008).

${ }^{163}$ See the discussion of ACLU v. Reno, infra, and the comparison between the CDA's provisions and the statute at issue in the Ginsberg case.

${ }^{164}$ Ashcroft v. Free Speech Coalition, 535 U.S. 234, 246 (2002). 
could legally consent to sexual relations, leading to the anomalous result in which an individual could consent to sexual relations yet be criminally prosecuted under CPPA for depicting such sexual relations.

\section{The Constitutionality of Prosecuting Sexting as Child Pornography}

A review of the Supreme Court's child pornography jurisprudence makes clear that sexting prosecutions like those described in Part II above cannot withstand constitutional scrutiny. First, typical acts of sexting do not depict sexual abuse or exploitation of children—the gravamen of legitimate child pornography claims. The state's interest in prosecuting acts of sexting is not the same as the interest recognized by the Supreme Court of drying up the market for content that constitutes a "proximate link to the crime" 165 of sexual exploitation or abuse of children. Second, acts of sexting typically occur in a noncommercial context, not in commercial or transactional contexts. Third, many incidents of sexting — like the Pennsylvania and Florida cases discussed above-involve mere depictions of nudity or partial nudity, which the Court has held are insufficient to constitute child pornography. Fourth, several instances of sexting, like in Phillip Alpert, ${ }^{166}$ A.H., and J.G.W., ${ }^{167}$ involve minors at or near the age of consent, which the Court has made clear are particularly problematic.

In addition, the Supreme Court has made clear that minors enjoy First Amendment rights to access and disseminate sexually themed expression of the kind typically involved in sexting communications. Although minors' First Amendment rights are not as extensive as those enjoyed by adults, they are extensive enough to protect the creation and dissemination of seminude and nude pictures of oneself that are not child pornography or obscene-for-minors (under

\footnotetext{
${ }^{165}$ Id. at 250.

166 See supra text accompanying notes 38-49.

167 See supra text accompanying notes 28-37.
} 
properly limited definitions of both terms). Indeed, the act of creating a photograph of oneself, like creating a self-portrait or writing in a diary, is an essential component of an individual's selfexpression, the furtherance of which is an essential function of the First Amendment. The next Part contends that prosecutions of minors for creating and sharing such images violate the First Amendment rights of the minors who are involved.

\section{The First Amendment Rights of Minors}

Although minors' First Amendment rights are not as extensive as those enjoyed by adults, the Supreme Court has made it clear that minors enjoy meaningful rights to freedom of expression in general. As the Court explained in Erznoznik v. City of Jacksonville, minors are entitled to a significant measure of First Amendment protection and only in relatively narrow and well-defined circumstances may government bar public dissemination of protected materials to them....

....

... In most circumstances, the values protected by the First Amendment are no less applicable when government seeks to control the flow of information to minors. ${ }^{168}$

The Court has also held that minors enjoy meaningful rights to access sexually themed content. This Part first examines the philosophical underpinnings of free speech rights in general and then considers these foundations as applied to minors in particular. It outlines the general contours of minors' First Amendment rights and examines these rights in the context of sexually themed content.

In considering the contours of minors' free speech rights, it is helpful to return to the philosophical underpinnings and justifications for free speech rights in general and to consider how these are translated in the context of minors' interests in free expression. Among the most important justifications for protecting freedom of expression is the integral role this protection

\footnotetext{
168422 U.S. 205, 212-14 (1975) (emphasis added) (citations omitted).
} 
plays in self-exploration, self-expression, and self-definition. Although the Court frequently refers to the importance of free speech in establishing the preconditions for democratic selfgovernment and in advancing the free and open marketplace of ideas, ${ }^{169}$ it has also made clear that "the individual's interest in self-expression is a concern of the First Amendment separate from the concern for open and informed discussion." ${ }^{170}$ As David Richards explains, the First Amendment "rests not only on [the] value of creating an informed electorate, but also rests on the deeper moral premises regarding the general exercise of autonomous expressive and judgmental capacity and the good that this affords in human life." ${ }^{171}$ Similarly, in the words of pre-eminent First Amendment scholar Thomas Emerson, individual self-fulfillment depends upon the development of an individual's capacity for reasoning and emotions, self-exploration, self-expression, and self-definition in order to form "an integral part of the development of ideas, of mental exploration and of the affirmation of self.” ${ }^{172}$ This justification presupposes that adults are engaged in the active process of self-definition and re-definition, which is facilitated through their enjoyment of First Amendment freedoms. Yet minors, if anything, are even more deeply entrenched in the process of self-exploration and self-definition. Consistent with this justification for First Amendment freedoms, it is important to protect minors' right to express themselves and to access the expression of others, so as to facilitate their process of selfexploration, self-expression, and self-definition.

\footnotetext{
169 See, e.g., Melville B. Nimmer, Does Copyright Abridge the First Amendment Guarantees of Free Speech and Press?, 17 UCLA L. REV. 1180, 1187 (1970).

170 See First Nat'l Bank of Boston v. Bellotti, 435 U.S. 765, 777 n.12 (1977).

${ }^{171}$ David. A.J. Richards, Free Speech and Obscenity Law: Toward a Moral Theory of the First Amendment, 123 U. PA. L. REV. 45, 69 (1974).

172 Thomas I. Emerson, Toward a General Theory of the First Amendment, 72 YALE L.J. 877, 879 (1963).
} 
The Supreme Court expounded upon the self-expression justification for First

Amendment freedoms in Procunier v. Martinez, in which the Court struck down restrictions on the ability of prisoners to communicate with the outside world. ${ }^{173}$ Although prisoners (like minors) enjoy free speech rights that are not as robust as those enjoyed by free adults, the Court emphasized the important role the First Amendment serves in advancing individual selfexpression:

The First Amendment serves not only the needs of the polity but also those of the human spirit-a spirit that demands self-expression. Such expression is an integral part of the development of ideas and a sense of identity. To suppress expression is to reject the basic human desire for recognition and affront the individual's worth and dignity. Such restraint may be "the greatest displeasure and indignity to a free and knowing spirit that can be put upon him.” ... It is the role of the First Amendment and this Court to protect those precious personal rights by which we satisfy such basic yearnings of the human spirit. ${ }^{174}$

Indeed, in expounding on the importance of self-expression to our First Amendment freedoms, the Court expressly incorporated the right to access sexually themed expression in the privacy of one's home, which the Court held is protected in the case Stanley v. Georgia. ${ }^{175}$ Accordingly, the Court has contemplated that the First Amendment's protections for self-exploration and selfexpression incorporate the right to access sexually themed expression.

The Court has also emphasized other important values served by the First Amendment, including access to a wide range of ideas and information that apply not only to adults but also to minors. As the Court held in the famous Pico case, in which it restricted a school board's discretion to remove books from school libraries:

173416 U.S. 396 (1974). These regulations “proscribed inmate correspondence that 'unduly complain[ed],' 'magnif[ied] grievances,' ‘express[ed] inflammatory political, racial, religious or other views or beliefs,' or contained matter deemed 'defamatory' or 'otherwise inappropriate.'” Id. at 396 (alterations in original).

${ }^{174}$ Id. at 427-28 (Marshall, J., concurring) (emphasis added) (citations omitted).

175 Stanley v. Georgia, 394 U.S. 557 (1969) (First Amendment protects individual’s right to view obscene publications in the privacy of his own home). 
Our precedents have focused not only on the role of the First Amendment in fostering individual self-expression but also on its role in affording the public access to discussion, debate, and the dissemination of information and ideas. ... ....

... [S]tudents must always remain free to inquire, to study and to evaluate, to gain new maturity and understanding. ${ }^{176}$

Similarly, in striking down a public school's decision to suspend minors for wearing black armbands to protest the Vietnam War, the Court explained that:

In the absence of a specific showing of constitutionally valid reasons to regulate their speech, students are entitled to freedom of expression ....

....

... The Nation's future depends upon leaders trained through a wide exposure to that robust exchange of ideas which discovers truth out of a multitude of tongues, [rather] than through any kind of authoritative selection. ${ }^{177}$

In sum, the First Amendment justification of facilitating individuals' self-expression, selfexploration, and self-definition is of pre-eminent importance, especially as applied to minors, who are entrenched in this self-evolutionary process.

First Amendment protections also facilitate the goals of democratic self-government. ${ }^{178}$ Although this justification applies directly only to individuals who have reached the age of majority and are formally capable of voting and engaging in the task of self-government, it applies indirectly to minors as well. During youth, individuals are and should be engaged in the process of acquiring the tools they need to engage in self-government when they do reach the age of majority. Older minors especially must be accorded broad access to a wide variety of content to develop these tools. Striking down efforts to restrict minors' access to violent video game content, Judge Richard Posner explains in American Amusement Machine Ass'n v. Kendrick:

\footnotetext{
${ }^{176}$ Island Trees Union Free Sch. Dist. No. 26 v. Pico, 457 U.S. 853, 866, 868 (1982) (citations omitted) (internal quotation marks omitted).

177 Tinker v. Des Moines Indep. Cmty. Sch. Dist., 393 U.S. 503, 511-12 (1969) (alteration in original) (emphasis added) (internal quotation marks omitted).

${ }^{178}$ See generally AleXander MeiKlejohn, Free Speech and Its Relation to Self-Government (1948).
} 
Now that eighteen-year-olds have the right to vote, it is obvious that they must be allowed the freedom to form their political views on the basis of uncensored speech before they turn eighteen, so that their minds are not a blank when they first exercise the franchise. ... People are unlikely to become well-functioning, independent-minded adults and responsible citizens if they are raised in an intellectual bubble. ${ }^{179}$

Similarly, the Supreme Court rejected the state's effort to compel students to pledge allegiance to the flag in West Virginia State Board of Education v. Barnette, explaining that "educating the young for citizenship is reason for scrupulous protection of Constitutional freedoms of the individual, if we are not to strangle the free mind at its source and teach youth to discount important principles of our government as mere platitudes." ${ }^{180}$ Protecting minors' freedom of expression is necessary to allow them to experience and experiment with the freedoms necessary to exercise meaningful rights of self-government. The closer an individual is to the age of majority, the more extensive are her free speech rights. Adolescence marks a transitional period in which individuals should enjoy and experience many of the freedoms that they will come to enjoy fully in adulthood so that they will be better able to meaningfully enjoy those freedoms when they come of age. Our system of free expression should ensure that adolescents are able to inform themselves and contribute to the public discourse even though they cannot yet participate in public elections. As the Supreme Court emphasized in Keyishian v. Board of Regents of the University of New York, “[t]he Nation’s future depends upon leaders trained through wide exposure to [the] robust exchange” of ideas and information. ${ }^{181}$

The Supreme Court has also made clear that older minors enjoy a First Amendment right to engage in and access sexually themed expression, so long as such expression is not obscene,

\footnotetext{
179244 F.3d 572, 577 (7th Cir. 2001).

180 W. Va. State Bd. of Educ. v. Barnette, 319 U.S. 624, 637 (1943).

${ }^{181}$ Keyishian v. Bd. of Regents of the Univ. of N.Y., 385 U.S. 589, 603 (1967).
} 
“obscene-for-minors,” or child pornography. Although minors’ First Amendment rights

regarding sexually explicit materials are more limited than adults' rights, they are nonetheless

substantial.

Reno v. ACLU is instructive in articulating the contours of minors' First Amendment

rights regarding sexually themed expression. ${ }^{182}$ The Supreme Court struck down the

Communications Decency Act's (CDA) criminal prohibitions on the transmission of indecent

messages to minors ${ }^{183}$ and on the display of patently offensive messages to minors. ${ }^{184}$ The fact

that both of these prohibitions were limited by affirmative defenses made available for those who

undertook good faith actions to restrict minors' access to the prohibited communications did not

save the provisions. ${ }^{185}$ In evaluating the constitutionality of these prohibitions, the Supreme

Court first compared them to the restrictions at issue in Ginsberg v. New York, in which the

182 See 521 U.S. 844 (1997).

183 The first provision prohibits the knowing transmission of obscene or indecent messages to any recipient under 18 years of age. 47 U. S. C. § 223(a) (Supp. 1997) ("Whoever-(1) in interstate or foreign communications ... (B) by means of a telecommunications device knowingly-(i) makes, creates, or solicits, and (ii) initiates the transmission of, any comment, request, suggestion, proposal, image, or other communication which is obscene or indecent, knowing that the recipient of the communication is under 18 years of age, regardless of whether the maker of such communication placed the call or initiated the communication; ... (2) knowingly permits any telecommunications facility under his control to be used for any activity prohibited by paragraph (1) with the intent that it be used for such activity, shall be fined under Title 18, or imprisoned not more than two years, or both.”).

184 The second provision prohibits the knowing sending or displaying of patently offensive messages in a manner that is available to a person under 18 years of age. Id. § 223(d) ("Whoever-(1) in interstate or foreign communications knowingly-(A) uses an interactive computer service to send to a specific person or persons under 18 years of age, or (B) uses any interactive computer service to display in a manner available to a person under 18 years of age, any comment, request, suggestion, proposal, image, or other communication that, in context, depicts or describes, in terms patently offensive as measured by contemporary community standards, sexual or excretory activities or organs, regardless of whether the user of such service placed the call or initiated the communication; or (2) knowingly permits any telecommunications facility under such person's control to be used for an activity prohibited by paragraph (1) with the intent that it be used for such activity, shall be fined under Title 18, or imprisoned not more than two years, or both.”).

${ }^{185}$ See id. § 223(e)(5) (extending affirmative defenses to those who take "good faith, reasonable, effective, and appropriate actions" to restrict access by minors to the prohibited communications and to those who restrict access to covered material by requiring certain designated forms of age proof, such as a verified credit card or an adult identification number or code). 
Court first recognized a category of obscene-for-minors speech that could be regulated under a different standard than obscene speech (for adults). ${ }^{186}$

The Reno Court explained that because the CDA's restrictions did not embody similar safeguards to those in the New York statute, it unconstitutionally infringed on minors' (and adults') free speech rights. ${ }^{187}$ In Ginsberg, the Supreme Court upheld a New York statute that regulated minors' access to content that fell within the statute's definition of “obscene for minors." 188 The state statute primarily aimed to restrict the sale of "girlie" magazines to minors. It prohibited the sale of materials considered obscene for minors (although not necessarily obscene for adults) to individuals age sixteen and under. ${ }^{189}$ In accordance with the Supreme Court cases that require regulation of obscene speech to include a savings clause, ${ }^{190}$ the New York statute exempted from regulation material that has redeeming social importance to minors. Upholding the statute against constitutional challenge, the Court emphasized the fact that the statute's operation did not usurp parental autonomy to determine what material was suitable for their children in that the statute allowed "parents who so desire [to] purchas[e] the magazines for their children.”191

Ginsberg therefore stands for the principle that minors' speech can be regulated under a different standard than that applicable to adults' speech, so long as the relevant regulation

${ }^{186}$ See 390 U.S. 629, 636 (1968) (The state "can exercise its power to protect the health, safety, welfare, and morals of its community by barring the distribution to children of books recognized to be suitable for adults.").

${ }^{187}$ Reno v. Am. Civil Liberties Union, 521 U.S. 844 (1997).

${ }^{188}$ Id. at 631-33.

${ }^{189}$ Id. at $645-47$.

${ }^{190}$ See Roth v. United States, 354 U.S. 476, 487 (1957) (“The portrayal of sex, e.g. in art, literature and scientific works, is not itself sufficient reason to deny material the constitutional protection of freedom of speech and press.").

${ }^{191}$ Ginsberg, 390 U.S. at 639. 
adheres to certain safeguards. These safeguards include the definitional safeguards set forth in Miller ${ }^{192}$ tailored to apply to minors, including a savings clause for speech that has redeeming social importance for minors and a patently offensive and prurient interest analysis undertaken in light of contemporary community standards. Requiring a savings clause in this context makes clear that any such regulation must preserve minors' access to expression that has serious literary, artistic, scientific, or political value. ${ }^{193}$

In Reno, the Court compared the indecent transmission and patently offensive display provisions of the CDA to those provisions at issue in Ginsberg and found that the CDA's provisions were constitutionally infirm. ${ }^{194}$ First, the Court held that the CDA was infirm because it defined "minor" as everyone under eighteen, where the New York statute defined "minor" as everyone under seventeen. ${ }^{195}$ Because the CDA reduced the First Amendment rights of those nearest to the age of majority, it did not meet constitutional muster. ${ }^{196}$ The Court's analysis on this point suggests that seventeen-year-old minors' First Amendment rights must be construed as extensively as adults' First Amendment rights, including their right to engage in and access sexually themed expression. Second, while the New York statute was appropriately tailored in line with Miller by limiting its definition of "material that is harmful to minors" with the requirement that it be "without redeeming social importance for minors," the CDA failed to provide any definition of the term "indecent." The CDA also omitted any requirement that the "patently offensive” material covered by § 223(d) lack serious literary, artistic, political, or

\footnotetext{
192 See supra text accompanying notes 102-109.

193 See supra text accompanying notes 108-109.

${ }^{194}$ Reno v. ACLU, 521 U.S. 844, 864-67 (1997).

${ }^{195}$ Id. at 865-66.

${ }^{196} I d$.
} 
scientific value. ${ }^{197}$ The Court explained that "[t]his 'societal value’ requirement, absent in the CDA, allows appellate courts to impose some limitations and regularity on the definition by setting, as a matter of law, a national floor for socially redeeming value.”198 Third, while in Ginsberg, the statute's prohibition against sales to minors did not bar parents from purchasing the magazines for their children, under the CDA, “neither the parents' consent—nor even their participation — in the communication would avoid the application of the statute." ${ }^{199}$ Refusing to account for parental discretion on this score disregards the Supreme Court’s “consistent recognition of the principle that 'the parents' claim to authority in their own household to direct the rearing of their children is basic in the structure of our society.'”200 Finally, the New York statute at issue in Ginsberg applied only to commercial transactions, whereas the CDA contained no such limitation. ${ }^{201}$

An analysis of Ginsberg and Reno, together with the Supreme Court's child pornography jurisprudence, indicate that minors enjoy a First Amendment right to communicate and access content that is not proximately linked to actual child abuse or exploitation. This right to communicate encompasses the noncommercial communication of sexually themed material that has societal value for minors and is not obscene for minors. And any attempt by the state to regulate minors' communication of sexually themed content must take care to preserve parents’ authority in their own households to make determinations as to which sexually themed content their children will have the right to access and exchange.

\footnotetext{
${ }^{197}$ Id. at 865.

${ }^{198}$ Id. at 873 .

${ }^{199} \mathrm{Id}$. at 865.

${ }^{200}$ Id. (citing Ginsberg, 390 U.S. at 639).

${ }^{201}$ Id.
} 


\section{Proposed Revisions to Child Pornography Laws to Exempt Sexting}

State and federal child pornography laws do not sufficiently protect minors' free speech rights. Such laws cannot constitutionally be applied to minors engaged in incidents of sexting. These laws should be revised to specifically exempt sexting engaged in by consenting teens, as described in Part I. Non-obscene depictions of nudity or sexual activity created by teens and exchanged voluntarily for noncommercial purposes should be specifically excluded from the definition of child pornography or related crimes. Child pornography and related laws should be amended to exempt sexually themed images that are voluntarily and consensually produced and made available by teens in a noncommercial context.

The state of Vermont has taken precisely such an approach and should serve as a model to other states and the federal government. The Vermont legislature recently amended its Sex Trafficking of Children statute to specifically exclude application to persons eighteen and younger, where the minor photographed is "at least 13 years old, and the child knowingly and voluntarily and without threat or coercion use[s] an electronic communication device to transmit an image of himself or herself to another person." ${ }^{202}$ This legislation allows prosecutors to send teenage "sexting" cases to juvenile courts to eliminate the stigma that accompanies child

\footnotetext{
${ }^{202}$ See 2009 Vt. Acts \& Resolves No. 58 (Vt. 2009) (“No person shall knowingly: (1) recruit, entice, harbor, transport, provide, or obtain by any means a person under the age of 18 for the purpose of having the person engage in a commercial sex act; (2) compel a person through force, fraud, or coercion to engage in a commercial sex act; or (3) benefit financially or by receiving anything of value from participation in a venture, knowing that force, fraud, or coercion was or will be used to compel any person to engage in a commercial sex act as part of the venture.") (to be codified at VT. STAT. ANN. tit. 13, § 2635a(b)); ("This section shall not apply if the person is less than 19 years old, the child is at least 13 years old, and the child knowingly and voluntarily and without threat or coercion used an electronic communication device to transmit an image of himself or herself to the person. ...") (to be codified at VT. STAT. ANN. tit. 13, § 2822(c)); ("This section shall not apply if the person is less than 19 years old, the child is at least 13 years old, and the child knowingly and voluntarily and without threat or coercion used an electronic communication device to transmit an image of himself or herself to the person.”) (to be codified at VT. STAT. ANN. tit. 13, § 2824(c)); ("This section shall not apply if the person is less than 19 years old, the child is at least 13 years old, and the child knowingly and voluntarily and without threat or coercion, used an electronic communication device to transmit an image of himself or herself to the person.”) (to be codified at VT. STAT. ANN. tit. 13, $\S 2827(d))$.
} 
pornography convictions. This legislation also prevents prosecutors from labeling juveniles convicted of sexting as sex offenders. Under Vermont's revised law, even minors convicted of this behavior more than once would not be eligible for sex offender status (although under the legislation they may be prosecuted in a district court rather than family or juvenile court).

Several other states have taken the approach of providing an educational, rather than a criminal law, solution to the problem of sexting. In the wake of a 2009 incident in which a fourteen-year-old girl was charged with distributing child pornography for posting nude images of herself on her MySpace account, New Jersey legislators proposed alternatives to criminal prosecutions for those engaging in sexting. ${ }^{203}$ Such proposed legislation creates a diversionary program where minors charged with creating or disseminating sexually explicit images can avoid prosecution by completing an educational program focusing on the legal and non-legal consequences (including the effect on relationships and the loss of future job opportunities) of such acts. ${ }^{204}$ Under the proposed legislation, prosecutors have the discretion to divert any minor charged with distribution of nude or sexually explicit images into the program.

States should follow the lead of Vermont and New Jersey and revise their child pornography and related laws to expressly exempt typical incidents of sexting, consistent with the protections the First Amendment extends to minors communicating non-obscene sexually themed expression that does not constitute a proximate link to sexual abuse or exploitation of children. Congress should follow this lead as well and revise federal child pornography laws to recognize and protect minors' rights to engage in sexually themed communications of the kind described above.

\footnotetext{
${ }^{203}$ See S. 2926, 213th Leg. (N.J. 2009); see also Toutant, supra note 52.

${ }^{204}$ S. 2926, 213th Leg. (N.J. 2009).
} 
If legislators are unwilling to assume the important but politically unpopular task of revising their child pornography laws to account for the First Amendment rights of minors, then courts construing such laws should recognize and protect these rights. The first appellate court to construe state child pornography laws as applied to sexting did just that in Miller $v$. Mitchell. ${ }^{205}$ In that case, the underlying facts of which were discussed above, ${ }^{206}$ the district attorney threatened to prosecute several teenagers under child pornography laws unless they attended an extensive education program designed by the district attorney. ${ }^{207}$ The parents of three of the implicated girls sued the district attorney under § 1983, claiming that this action constituted retaliation against their daughters in violation of the girls' First Amendment rights to appear in the photographs, the girls' right to be free from being compelled to attend the reeducation program, and the parents' substantive due process rights to direct their children's upbringing. ${ }^{208}$

The district court ruled in favor of the parents, finding, inter alia, that because the pictures were not illegal under Pennsylvania's child pornography law, the only reason to prosecute them would be in retaliation for exercising their constitutional right not to participate in the district attorney's education program. ${ }^{209}$ In enjoining the district attorney from initiating criminal charges against the girls in connection with the photographs or their refusal to attend the education program, the district court found that under Pennsylvania law, "plaintiffs make a reasonable argument that the images presented to the court do not appear to qualify in any way

\footnotetext{
205598 F.3d 139 (3d Cir. 2010).

206 See text accompanying supra notes Error! Bookmark not defined.-27.

${ }^{207}$ Miller v. Mitchell, 598 F.3d at 143-44.

${ }^{208}$ Id. at $147-48$.

${ }^{209}$ Miller v. Skumanick, 605 F. Supp. 2d 634 (M.D. Pa. 2009). aff'd sub nom. Miller v. Mitchell, 598 F.3d 139.
} 
as depictions of prohibited sexual acts.” ${ }^{210}$ The Third Circuit affirmed, holding that the education program required by the district attorney impermissibly violated the daughters’ First Amendment right not to engage in compelled speech and the parents' right to raise their children without undue state interference. ${ }^{211}$

In summary, legislatures should revise their child pornography laws to exempt acts of sexting from their reach and ensure that such laws are not used to harm the very people they were designed to protect. Failing that, courts should construe state child pornography laws consistent with Supreme Court precedent to protect the First Amendment rights of the minors involved and the due process rights of their parents to direct the upbringing of their children free of undue state interference.

\section{Privacy Not Pornography}

\section{A. Public Disclosure of Private Facts}

In some examples discussed in Part II, nude or sexually themed images of minors, initially created with the subject's permission, were then disseminated or otherwise made available beyond the scope of the subject's consent. This Article contends that although such incidents do not support criminal child pornography charges, they may nonetheless constitute harmful and actionable invasions of privacy.

Under most states' privacy laws, the transmission of a nude or sexually explicit picture without the subject's consent constitutes an invasion of privacy as a publication of a private "fact." ${ }^{212}$ As set forth in the Restatement (Second) of Torts:

\footnotetext{
${ }^{210}$ Id. at 645.

${ }^{211}$ Mitchell, 598 F. 3d at 155.

212 See infra note 215 and accompanying text.
} 
One who gives publicity to a matter concerning the private life of another is subject to liability to the other for invasion of his privacy, if the matter publicized is of a kind that

(a) would be highly offensive to a reasonable person, and

(b) is not of legitimate concern to the public. ${ }^{213}$

Although there is a First Amendment defense for the publication of information or images revealing private facts that are "newsworthy" or otherwise a legitimate matter of public concern, in the overwhelming majority of sexting cases — where one teenager forwards a nude picture of the subject to other friends or classmates, for example-this “newsworthiness” exception would not apply. Furthermore, under the public disclosure of private facts branch of the invasion of privacy tort, truth does not serve as an affirmative defense. ${ }^{214}$ The publication of the private facts tort encompasses, for example, making available information about the fact that an individual has a sexually transmitted disease or revealing information about a person’s sexual orientation, if such information has not previously been revealed to the public, is not legitimately newsworthy, and if publication of this information would be offensive to a reasonable person. The public disclosure of private fact tort would encompass acts of sexting in which an image is shared without or beyond the subject's consent.

Courts in many jurisdictions have held that the dissemination of nude, semi-nude, or similarly revealing pictures of an individual without or beyond that individual's consent are actionable invasions of privacy as publications of private facts. ${ }^{215}$ In G.J.D. v. Johnson, for

\footnotetext{
${ }^{213}$ RESTATEMENT (SECOND) OF TORTS § 652D (1977).

${ }^{214}$ See 62A AM. JuR. 2D Privacy § 175 (2011) (“Truth, while a defense to an action of libel, is not a defense to an action for an invasion of the right of privacy.”) (footnotes omitted).

${ }^{215}$ See York v. Story, 324 F.2d 450 (9th Cir. 1963) (police taking and circulating nude photographs of plaintiff, which were allegedly taken to obtain evidence of bruises from assault, may give rise to an invasion of privacy claim); Daily Times Democrat v. Graham, 162 So. 2d 474 (Ala. 1964) (defendant newspaper liable for publishing photograph of plaintiff's skirt blowing up over her waist at county fair fun house); Taylor v. K.T.V.B., Inc., 525 P.2d 984 (Idaho 1974) (television station that aired footage of plaintiff being arrested and emerging naked from his house could be held liable for invasion of privacy); Wood v. Hustler Magazine, Inc., 736 F.2d 1084 (5th Cir. 1984);
} 
example, the Pennsylvania Supreme Court affirmed an award of compensatory and punitive damages to a woman whose former partner distributed nude pictures of her throughout the community. ${ }^{216}$ Similarly, in a case where a plaintiff voluntarily created nude photographs of herself on film and brought the film to defendant's photofinishing shop to be developed, the defendant was found liable for invasion of privacy when an employee developed and circulated those photographs to a group of individuals without the plaintiff's consent. ${ }^{217}$ Further, in a case where the plaintiff consented to be photographed nude for the limited purpose of publication in a book, the court held the defendant liable for invasion of privacy because he exceeded the scope of the consent by publishing one of the photographs in a newspaper. ${ }^{218}$ Some courts have held that posting on the Internet video footage of individuals engaging in sexual activity constitutes a violation of the individuals' right to privacy (even where the subject is a public figure, such as Pamela Lee Anderson, who previously consented to making other nude photos available to the public). ${ }^{219}$

Solano v. Playgirl, Inc., 292 F.3d 1078 (9th Cir. 2002). See generally Myers v. U.S. Camera Publ'g Corp., 167 N.Y.S.2d 771 (N.Y. City Ct. 1957) (nudity is a private fact giving rise to damages when shown beyond persons to whom consent is given); Gallon v. Hustler Magazine, Inc., 732 F. Supp. 322 (N.D.N.Y. 1990) (publication of nude photograph without authorization is an invasion of privacy). For academic commentary, see generally Peter B. Edelman, Free Press v. Privacy: Haunted by the Ghost of Justice Black, 68 TEX. L. REV. 1195, 1209 n.74 (1990) (noting cases that allowed recovery when defendants published nude or revealing photographs, odd and disfiguring medical conditions, and details from the plaintiff's past life); Patrick J. McNulty, The Public Disclosure of Private Facts: There Is Life After Florida Star, 50 DrAKE L. REV. 93, 105-06 (2001); John A. Jurata, Jr., Comment, The Tort that Refuses to Go Away: The Subtle Reemergence of Public Disclosure of Private Facts, 36 SAN DIEGO L. REV. 489, 510-30 (1999).

$$
{ }^{216} 669 \text { A.2d } 378 \text { (Pa. 1995). }
$$

${ }^{217}$ See Lake v. Wal-Mart Stores, Inc., 582 N.W.2d 231, 235 (Minn. 1998) (reversing trial court dismissal of complaint against Wal-Mart and its photo department employees who allegedly distributed nude photos of plaintiffs, and holding that the case could proceed under the privacy theory of public disclosure of private facts, among others).

${ }^{218}$ McCabe v. Village Voice, Inc., 550 F. Supp. 525 (E.D. Pa. 1982) (defendant newspaper liable when plaintiff consented to being photographed nude in the bathtub for publication in a book but not in a newspaper).

${ }^{219}$ Michaels v. Internet Entm’t Grp., 5 F. Supp. 2d 823 (C.D. Cal. 1998). 
Although posting a nude or sexually explicit image of an individual on the Internet would readily satisfy the "public" aspect of the public disclosure of private facts tort, it is less clear whether forwarding such an image to a handful of other acquaintances would satisfy this element. The case law suggests that, while revealing such images to one person does not suffice for "public" disclosure, sharing images with (at least) a handful of others-as occurs in the typical sexting context—would satisfy the publicity requirement. For example, in Lemnah $v$. American Breeders Service, Inc., the court held that where only one person had received the communication (that the plaintiff was fired for drunkenness), there was not the kind of publicity necessary to sustain a public disclosure of private fact claim. ${ }^{220}$ However, in several cases that involved dissemination of private information to (at least) a handful of other people, courts have considered such dissemination to be "public" enough to constitute a valid claim for public disclosure of a private fact. For example, in Bolduc v. Bailey, the defendant accused the plaintiff, a priest, of several criminal and moral offenses. ${ }^{221}$ The defendant communicated these accusations in a series of conversations with fellow members of the plaintiff's religious society. ${ }^{222}$ Even though the defendant did not communicate the accusations to the public at large — only to a limited group — the court found that the complaint properly pled an invasion of privacy for public disclosure of private facts. ${ }^{223}$

Accordingly, individuals who possess "sexting” images with the subject’s initial assent and further disseminate sexting images beyond the subject's initial consent are liable for invading the privacy of the subject, and are properly subject to damages and injunctive relief.

220482 A.2d 700, 704 (Vt. 1984).

${ }^{221} 586$ F. Supp. 896, 899 (D. Colo. 1984).

${ }^{222} I d$.

${ }^{223} I d$. at 901. 
For example, in the case described above in which Phillip Alpert e-mailed nude pictures of his former girlfriend to seventy of her e-mail contacts, Phillip would be liable in an invasion of privacy action brought by his former girlfriend for public disclosure of private facts for sharing this image with a large number of other individuals. ${ }^{224}$

\section{B. Intermediary Liability for Public Disclosure of Private Facts}

Individuals who disseminate nude, semi-nude or otherwise sexually explicit images of minors to others without or beyond the subject's consent should be held accountable under the publication of private fact branch of the invasion of privacy tort. However, the subject's ability to sue the disseminator for damages or injunctive relief may provide incomplete relief, especially in circumstances in which the image is made available by a website run by another party such as MySpace or Facebook. Given the current state of the law, it is exceedingly difficult for an individual to hold a website liable in tort for any type of harm resulting from the website's publication of an image. While these social networking sites generally undertake measures to remove such images (once made aware of them), 47 U.S.C. § 230, enacted by the CDA, immunizes such sites from liability for their role in making such images available. ${ }^{225}$ Below, this Article argues that § 230(c) should be revised or reinterpreted by courts to reach a more privacy-protective outcome.

In passing the Communications Decency Act of 1996, Congress sought to remedy perceived ills caused by certain types of offensive expression on the Internet using two different approaches. First, the CDA prohibited the transmission of certain types of sexually themed

\footnotetext{
224 See supra text accompanying notes 38-49.

${ }^{225}$ Pub. L. No. 104-104, § 509, 110 Stat. 133, 138 (codified as amended at 47 U.S.C. § 230 (2006)).
} 
expression on the Internet. ${ }^{226}$ These provisions prohibiting the transmission of "indecent”"227 content and prohibiting the display of "patently offensive” 228 content were insufficiently attentive to the First Amendment rights of individuals, and, as discussed above, ${ }^{229}$ were quickly struck down by the Supreme Court. ${ }^{230}$ Second, Congress also sought to respond to earlier decisions that held websites liable for defamatory content posted by subscribers. Earlier cases treated websites as publishers of information made available by the website's subscribers and held the websites secondarily liable for defamation and related torts. In one early case in particular, Stratton Oakmont, Inc. v. Prodigy Services Co., the website had reserved and exercised editorial control over the content made available by its subscribers. ${ }^{231}$ The court in Stratton Oakmont held that such control rendered the website a publisher of the defamatory content made available by its subscriber. ${ }^{232}$ In response to pleas by website owners to immunize them from liability in such circumstances, Congress passed § 230(c), which both encourages websites to continue to engage in acts of good faith exercises of editorial control—such as by blocking objectionable material ${ }^{233}$ _and immunizes them from liability for publishing or distributing harmful material made available by their subscribers. This provision of $\S 230(c)$

${ }^{226}$ Id. § 502, 110 Stat. at 133-134 (codified as amended at 47 U.S.C. § 223).

${ }^{227}$ See supra text accompanying note 197.

${ }^{228}$ See supra text accompanying note 197.

229 See supra text accompanying notes 197-206.

${ }^{230}$ See, e.g., Reno v. ACLU, 521 U.S. 844 (1997).

${ }^{231}$ No. 31063/94. 1995 WL 323710 (N.Y. Sup. Ct. 1995).

${ }^{232} I d$. at $* 4$.

23347 U.S.C. § 230(c)(2) (2006) ("No provider ... of an interactive computer service shall be held liable on account of . . . any action voluntarily taken in good faith to restrict access to or availability of material that the provider . . . considers to be obscene, lewd, lascivious, filthy, excessively violent, harassing, or otherwise objectionable, whether or not such material is constitutionally protected ....”). 
stipulates that " $[\mathrm{n}] \mathrm{o}$ provider . . . of an interactive computer service shall be treated as the publisher or speaker of any information provided by another information content provider.”234 These provisions of the CDA achieve their purpose to the extent that they immunize interactive computer services and websites from liability, like Prodigy, that cannot be expected to control ex ante every post made by every subscriber. ${ }^{235}$ Since this provision became law, however, countless websites have successfully claimed immunity from a broad range of lawsuits for making available content posted by others_-both as an initial matter and after the harmful nature of such content has been asserted by the plaintiff. Indeed, courts have extended § 230(c)'s immunity well beyond defamation, to other state causes of action, such as negligence and gross negligence, ${ }^{236}$ nuisance, ${ }^{237}$ sending threatening messages, ${ }^{238}$ and even statutory violations of the

${ }^{234} I d$. § 230(c)(1). Although the statutory language here refers to "interactive computer service,” which is defined as "any information service, system, or access software provider that provides or enables computer access by multiple users to a computer server," courts have held that web sites in general are encompassed by this definition. Id. § 230(f)(2).

${ }^{235}$ For example, in an early case involving $§ 230$ immunity, the Fourth Circuit extended broad immunity from liability to AOL for the defamatory post of an AOL subscriber. In Zeran v. America Online, Inc., 129 F.3d 327 (4th Cir. 1997), the court held that AOL was not liable for negligent distribution of defamatory material after an AOL user carried out a malicious hoax on the victim Zeran — even where AOL refused to take down the defamatory material upon learning of it. The plaintiff argued that $\S 230$ leaves intact liability for interactive computer service providers who possess notice of defamatory material posted through their services. The court rejected plaintiff's attempts to impose notice-based liability on ISPs, explaining that:

By its plain language, $\S 230$ creates a federal immunity to any cause of action that would make service providers liable for information originating with a third-party user of the service. Specifically, § 230 precludes courts from entertaining claims that would place a computer service provider in a publisher's role. Thus, lawsuits seeking to hold a service provider liable for its exercise of a publisher's traditional editorial functions-such as deciding whether to publish, withdraw, postpone or alter content-are barred.

Id. at 330 (emphasis added).

${ }^{236}$ See, e.g. Doe v. MySpace, 528 F.3d 413 (5th Cir. 2008) (upholding MySpace’s immunity from negligence and gross negligence liability for failing to institute safety measures to protect minors and for failure to institute policies relating to age verification, in a case in which the Doe's daughter had lied about her age and communicated over MySpace with a man who later sexually assaulted her).

${ }^{237}$ See, e.g., Kathleen R. v. City of Livermore, 104 Cal. Rptr. 2d 772 (Cal. Ct. App. 2001) (upholding city’s immunity from claims of nuisance, inter alia, where plaintiff's child downloaded pornography from a public library's computers which did not restrict Internet access to minors). 
Fair Housing Act and related anti-discrimination violations. ${ }^{239}$ Section 230 expressly provides that its immunity does not extend to federal criminal law, including liability for obscenity or for sexual exploitation of children, ${ }^{240}$ nor does it extend to liability for intellectual property violations. ${ }^{241}$ Additionally, the statute explicitly provides that it does not prevent states from enforcing any state law that is consistent with this section. ${ }^{242}$ However, in construing $\S 230$ in the context of defenses asserted by ISPs and websites, courts have extended this statutory provision unnecessarily broadly and have provided website defendants with immunity for hosting sexually explicit content that is inconsistent with the limited purpose of the statute. Consider, for example, Barnes v. Yahoo, in which the Ninth Circuit extended broad immunity to Yahoo. ${ }^{243}$ In 2004, Cecilia Barnes’s ex-boyfriend created unauthorized Yahoo profiles of Cecilia and posted nude pictures of Cecilia on the profiles. ${ }^{244}$ The profile pages provided Cecilia's work phone number and e-mail address and led viewers to believe that Cecilia

238 See, e.g., Delfino v. Agilent Techs., 52 Cal. Rptr. 3d. 376 (Cal. Ct. App. 2006), cert. denied, 552 U.S. 817 (2007) (upholding immunity from state tort claims arising from an employee's use of the employer's e-mail system to send threatening messages).

239 See Chicago Lawyers’ Comm. for Civil Rights Under Law, Inc. v. Craigslist, Inc., 519 F.3d 666 (7th Cir. 2008) (upholding § 230(c) immunity for online services provider Craigslist against Fair Housing Act claims based on discriminatory statements in postings on the classifieds website by third party users). But see Fair Hous. Council of San Fernando Valley v. Roommates.com, LLC, 521 F.3d 1157 (9th Cir. 2008) (en banc) (rejecting immunity for the Roommates.com roommate matching service for claims brought under the federal Fair Housing Act and California housing discrimination laws because the website created the questions used for discriminatory practices).

240 See 47 U.S.C. § 230(e)(1) (2006) ("Nothing in this section shall be construed to impair the enforcement of section 223 or 231 of this title, chapter 71 (relating to obscenity) or 110 (relating to sexual exploitation of children) of title 18, or any other Federal criminal statute.”).

${ }^{241}$ See id. $\S 230(\mathrm{e})(2)$ ("Nothing in this section shall be construed to limit or expand any law pertaining to intellectual property.”).

${ }^{242}$ See id. § 230(e)(3) ("Nothing in this section shall be construed to prevent any State from enforcing any State law that is consistent with this section. No cause of action may be brought and no liability may be imposed under any State or local law that is inconsistent with this section.”).

\footnotetext{
243 Barnes v. Yahoo!, Inc., 570 F.3d 1096 (9th Cir. 2009).

${ }^{244} I d$. at 1098.
} 
was seeking to engage in casual sexual relations. ${ }^{245}$ Not surprisingly, strangers began contacting Cecilia at work by phone and e-mail, as well as showing up at her workplace. ${ }^{246}$ Cecilia contacted Yahoo several times over the next few months to request that the profile be removed, to no avail. ${ }^{247}$ A local television reporter learned of Cecilia’s situation and began to prepare a news story on the subject. ${ }^{248}$ When the reporter contacted Yahoo on Cecilia’s behalf, Yahoo’s communications director promised that she would make sure the profiles were removed. ${ }^{249}$ When Yahoo still had not acted on its express promise to remove the profiles almost two months later, Cecilia brought suit against the company. ${ }^{250}$

In its decision, the Ninth Circuit held that Barnes’ tort claim against Yahoo for negligent undertaking was barred by $\S 230(c) .{ }^{251}$ However, Barnes was also able to assert a contractual claim of promissory estoppel against Yahoo for failing to make good on its express promise to remove the images. ${ }^{252}$ Only because Yahoo expressly promised to Barnes that it would promptly remove the offending material, but failed to do so, could Barnes proceed in her action against Yahoo. ${ }^{253}$ The Ninth Circuit made clear that absent an express promise on the part of the website hosting such offending content that it would remove such content, a plaintiff's claim will be barred by $\S 230(c){ }^{254}$

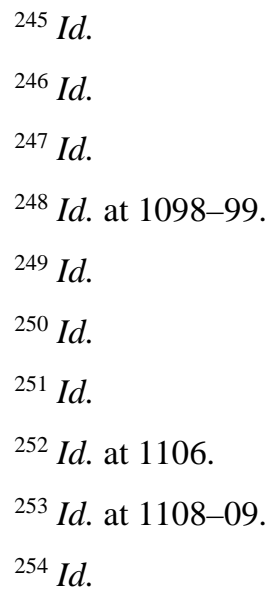


The immunity § 230 grants websites for harms arising from their subscribers’ speech has been extended too far. Websites like Yahoo and Facebook, presented with notice and clear evidence that the subject of a nude or sexually explicit image did not consent to posting the image (as in the Barnes v. Yahoo case), should be required to promptly remove that image or face liability for violating that individual's privacy. ${ }^{255}$ A similar regime in the copyright infringement context provides a helpful model. Under the Digital Millennium Copyright Act, a copyright owner who believes his or her material has been infringed may provide notice to a website stating his or her belief that the website is hosting infringing content. ${ }^{256}$ Upon receipt of such notice, the website must immediately cease hosting such allegedly infringing content in order to secure the benefits of the statute’s limitations on liability. ${ }^{257}$ Unlike $\S 230$, which courts have construed to provide broad immunity to websites regardless of whether they remove the offensive content identified by the subject, the corresponding copyright provisions require the website to act in good faith upon notice to remove the offending content in order to secure the limitation of liability. Although an obligation to remove such allegedly offensive content, if imposed too broadly, may lead to a chilling of free speech and fair use rights, ${ }^{258}$ in the limited context of nude or sexually explicit images that the subject can conclusively establish have been

\footnotetext{
${ }^{255}$ Like many U.S. states, the European Union does not hold Internet Service Providers (ISPs) liable so long as they only act as a conduit for information and do not participate in the content selection process. In contrast to the system in the U.S., however, ISPs in the E.U. are required to remove illegal content upon notification of such. See Council Directive 2000/31, art. 12-15, 2000 O.J. (L 178) 1 (EC). If the content is not removed, they can be held liable, as Google was in a recent Italian case involving a video of an autistic boy. Manuela D’Alessandro, Google Executives Convicted for Italy Autism Video, REUTERS, (Feb. 24, 2010, 5:40 PM), http://www.reuters.com/article/idUSTRE61N2G520100224. Here, the defendant successfully claimed that Google should have been on notice when the video became a headline news story, and not waited until police notified them of the illegal content. Furthermore, the EU permits ISPs to voluntarily monitor their sites for illegal content.

${ }^{256} 17$ U.S.C. $\S 512$ (c)(3).

${ }^{257} \mathrm{Id}$.

${ }^{258}$ See Jennifer M. Urban \& Laura Quilter, Efficient Process or "Chilling Effects”? Takedown Notices Under Section 512 of the Digital Millennium Copyright Act, 22 SANTA Clara COMPUTER \& High TeCH. L.J. 621(2006).
} 
posted without her consent, there is no similar danger that websites' free speech rights will be unduly chilled. In construing $\S 230$, courts should hold that a website that fails to remove such images upon notice and receipt of proper documentation from the subject has participated in the invasion of privacy and is indirectly liable for such conduct. Interpreting the statutory language that "[n]o [service] provider ... shall be treated as the publisher or speaker of any information provided by another information content provider," ${ }^{259}$ courts should conclude that when a website refuses to take down the images in a timely manner upon proper request, such material is no longer material that is made available by “another information content provider," but becomes material made available by the website itself, for which it is liable.

\section{Conclusion}

As teenagers explore their sexuality and seek to memorialize and exchange information related to their sexual development, their instantaneous ability to memorialize and share images with others, via cell phones or the Internet, presents a host of new problems to which our society must respond intelligently. The recent trend of harshly punishing these teens under the child pornography regime is not an intelligent solution. In light of this wave of prosecutorial overreaching, state and federal child pornography laws should be revised to specifically exempt sexting by minors from the reach of such laws. Child pornography laws were created to punish and deter a far different class of conduct—-the conduct of adult pedophiles creating and disseminating images that depict sexual abuse of their child victims in a commercial contextnot the conduct of older minors using technology to explore their sexuality and voluntarily exchange images with one another. Non-obscene depictions of nudity or sexual conduct created

25947 U.S.C. § 230(c)(1) (2006). 
by teens and exchanged voluntarily among themselves for noncommercial purposes should be specifically excluded from the applicable definitions of child pornography and similar crimes. Instances of sexting, however, should not necessarily go unpunished, as they may constitute harmful invasions of the subject's privacy. In cases in which nude or sexually themed images of minors, which were initially created with the subject's consent, are disseminated or otherwise made available without or beyond the scope of the subject's consent, such conduct should be cognizable as actionable invasions of the subject's privacy under the publication of private facts branch of this common law tort. The subject should be able to seek relief not only against the individual who made such images available without her consent, but also against a website that continues to host such images after being notified of their presence. Websites that continue to facilitate the hosting of such images after the subject requests their removal should lose their immunity for hosting such content and should be held liable for facilitating the invasion of the subject's privacy. 